In cooperation with the Kentucky Department of Agriculture

Concentrations, and Estimated Loads and Yields of Nutrients and Suspended Sediment in the Little River Basin, Kentucky, 2003=04

Scientific Investigations Report 2006-5204 
Cover Photograph. Art depiction of land protected with conversation buffers and other practices by Scott Patton, USDA, Natural Resources Conversation Service. 


\section{Concentrations, and Estimated Loads and Yields of Nutrients and Suspended Sediment in the Little River Basin, Kentucky, 2003-04}

By Angela S. Crain

In cooperation with the Kentucky Department of Agriculture

Scientific Investigations Report 2006-5204 


\section{U.S. Department of the Interior \\ DIRK KEMPTHORNE, Secretary \\ U.S. Geological Survey \\ P. Patrick Leahy, Acting Director}

\section{U.S. Geological Survey, Reston, Virginia: 2006}

For product and ordering information:

World Wide Web: http://www.usgs.gov/pubprod

Telephone: 1-888-ASK-USGS

For more information on the USGS--the Federal source for science about the Earth,

its natural and living resources, natural hazards, and the environment:

World Wide Web: http://www.usgs.gov

Telephone: 1-888-ASK-USGS

Any use of trade, product, or firm names is for descriptive purposes only and does not imply endorsement by the U.S. Government.

Although this report is in the public domain, permission must be secured from the individual copyright owners to reproduce any copyrighted materials contained within this report.

Suggested citation:

Crain, A.S., 2006, Concentrations, and Estimated Loads and Yields of Nutrients and Suspended Sediment in the Little River Basin, Kentucky, 2003-04: U.S. Geological Survey Scientific Investigations Report 2006-5204, 31 p.

The U.S. Geological Survey does not discriminate on the basis of race, color, national origin, sex, age, religion or disability and provides on request, reasonable accommodations including auxiliary aids and services necessary to afford an individual with a disability an equal opportunity to participate in all services, programs, and activities. These materials can be provided in alternative format to any individual with a disability. This work was supported, in part, by a grant from the U.S. Environmental Protection Agency under $\$ 319(\mathrm{~h})$ of the Clean Water Act through the Kentucky Division of Water to the Kentucky Department of Agriculture, Grant \# C9994861-01 KY. 


\section{Contents}

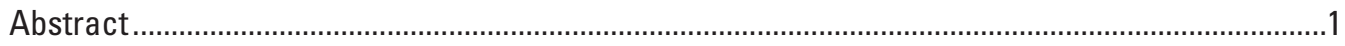

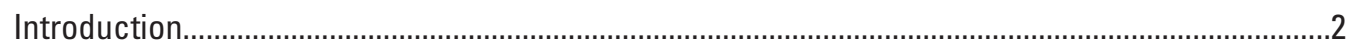

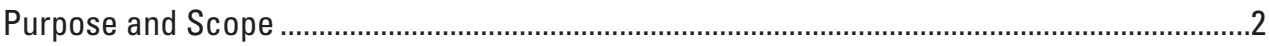

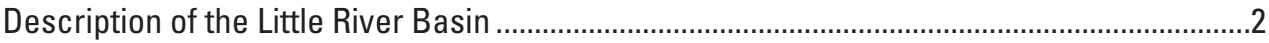

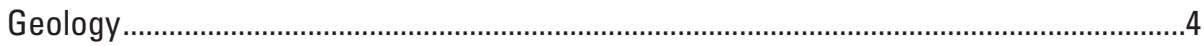

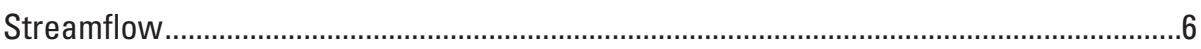

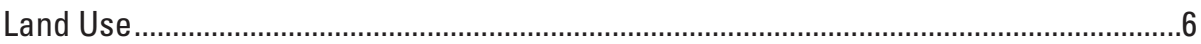

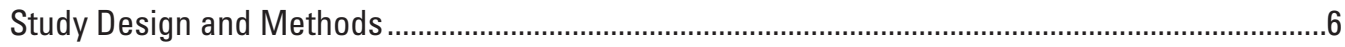

Sample-Site Selection and Sampling Frequency .............................................................6

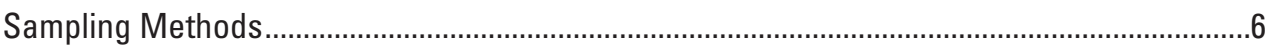

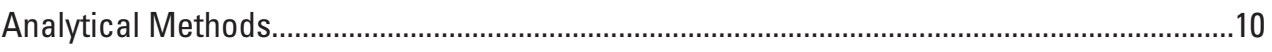

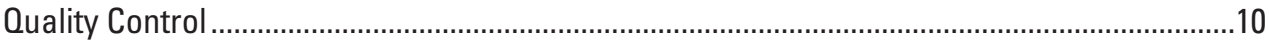

Statistical Analysis of Nutrients and Suspended Sediment.................................................10

Load-Estimation Methods ............................................................................................................11

Sources of Nitrogen and Phosphorus .................................................................................................11

Nonpoint-Source Contributions .............................................................................................11

Atmospheric Deposition ................................................................................................ 13

Commercial Fertilizer and Livestock Waste ...................................................................... 13

Nitrogen Fixation by Soybeans......................................................................................14

Point-Source Contributions..................................................................................................14

Concentrations, and Estimated Loads and Yields of Nutrients ....................................................15

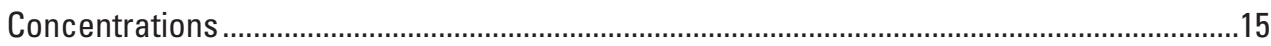

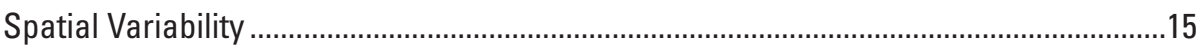

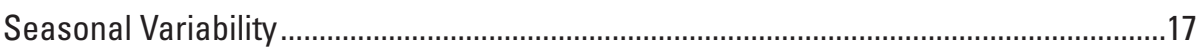

Estimated Loads and Yields....................................................................................................17

Concentrations, and Estimated Loads and Yields of Suspended Sediment....................................22

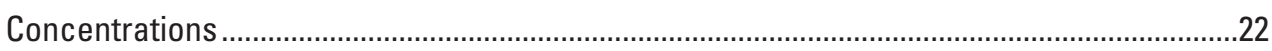

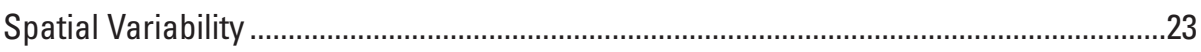

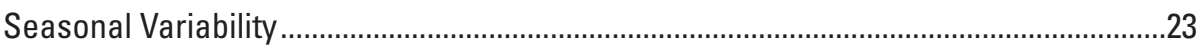

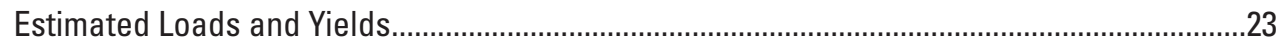

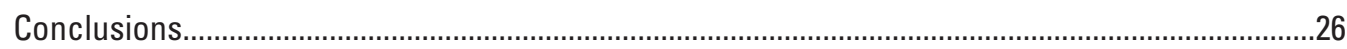

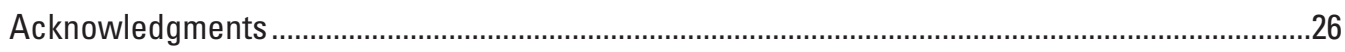

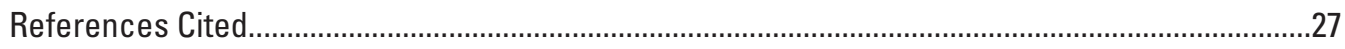

Appendix 1: Statistical summary of concentrations of ammonia nitrogen, nitrite plus nitrate, total phosphorus, orthophosphate, and suspended sediment in the Little River Basin, Kentucky, 2003-04 


\section{Figures}

1.-5. Maps showing:

1. Location of the surface-water-sampling sites in the Little River Basin, Kentucky, 2003-04 3

2. Surficial geology in the Little River Basin, Kentucky, 2003-04 ...............................................

3. Location of sinkholes in the Little River Basin, Kentucky, 2003-04 .........................................5

4. Location of surface-water samplings sites and graphs showing precipitation and daily mean streamflow at selected sites in the Little River Basin, Kentucky, 2003-04 ....7

5. Land cover in the Little River Basin, Kentucky, 2001 ..............................................................8

6.-10. Boxplots showing:

6. Concentrations of nitrite plus nitrate, total phosphorus, and orthophosphate at all sampling sites in the Little River Basin, Kentucky, 2003-04 ...................................16

7. Seasonal distribution of concentrations of nitrite plus nitrate for four fixed-network sites in the Little River Basin, Kentucky, 2003-04..................................................18

8. Seasonal distribution of concentrations of total phosphorus and orthophosphate for four fixed-network sites in the Little River Basin, Kentucky, 2003-04 ....................19

9. Concentrations of suspended sediment at all sampling sites in the Little River Basin, Kentucky, 2003-04

10. Seasonal distribution of concentrations of suspended sediment for four fixed-network sites in the Little River Basin, Kentucky, 2003-04...

\section{Tables}

1. Description of surface-water-sampling sites in the Little River Basin, Kentucky, 2003-04 ...........9

2. Reporting limits for nutrients as established by the U.S. Geological Survey National

Water-Quality Laboratory .................................................................................................10

3. Summary of replicate-sample data for nutrients and suspended sediment in the Little River Basin, Kentucky, 2003-04

4. Loads of nutrients and suspended sediment at three sites in the Little River Basin, Kentucky, 2003-04, using LOADEST predefined and user-defined models

5. Estimated mean annual loads of total nitrogen and total phosphorus from nonpoint and point sources in the Little River Basin, Kentucky, 2003-04.

6. Estimated mean annual loads of total nitrogen and total phosphorus from municipal wastewater discharge in the Little River Basin, Kentucky, 2003-04..

7. Estimated mean annual load and yield of nutrients and suspended sediment at the fixed-network sites in the Little River Basin, Kentucky, 2003-04.

8. Regression coefficients and coefficients for determination $\left(R^{2}\right)$ for load models used to estimate nitrite plus nitrate, total phosphorus, orthophosphate, and suspended sediment at three sites in the Little River Basin, Kentucky, 2003-04. 


\section{Conversion Factors and Abbreviations}

\section{Inch/Pound to SI}

\begin{tabular}{|c|c|c|}
\hline Multiply & By & To obtain \\
\hline \multicolumn{3}{|c|}{ Length } \\
\hline inch (in.) & 2.54 & centimeter $(\mathrm{cm})$ \\
\hline inch (in.) & 25.4 & millimeter (mm) \\
\hline \multicolumn{3}{|c|}{ Area } \\
\hline acre & 4,047 & square meter $\left(\mathrm{m}^{2}\right)$ \\
\hline acre & 0.4047 & hectare (ha) \\
\hline acre & 0.4047 & square hectometer $\left(\mathrm{hm}^{2}\right)$ \\
\hline acre & 0.004047 & square kilometer $\left(\mathrm{km}^{2}\right)$ \\
\hline square mile $\left(\mathrm{mi}^{2}\right)$ & 259.0 & hectare (ha) \\
\hline square mile $\left(\mathrm{mi}^{2}\right)$ & 2.590 & square kilometer $\left(\mathrm{km}^{2}\right)$ \\
\hline \multicolumn{3}{|c|}{ Flow rate } \\
\hline cubic foot per second $\left(\mathrm{ft}^{3} / \mathrm{s}\right)$ & 0.02832 & cubic meter per second $\left(\mathrm{m}^{3} / \mathrm{s}\right)$ \\
\hline million gallons per day (Mgal/d) & 0.04381 & cubic meter per second $\left(\mathrm{m}^{3} / \mathrm{s}\right)$ \\
\hline \multicolumn{3}{|c|}{ Mass } \\
\hline pound, avoirdupois (lb) & 0.4536 & kilogram (kg) \\
\hline \multicolumn{3}{|c|}{ Application rate } \\
\hline pounds per acre (lb/acre) & 1.121 & kilograms per hectare $(\mathrm{kg} / \mathrm{ha})$ \\
\hline pounds per day (lb/d) & 0.4536 & kilogram per day $(\mathrm{kg} / \mathrm{d})$ \\
\hline pounds per year (lb/yr) & 0.4536 & kilograms per year (kg/yr) \\
\hline pounds per square mile $\left(\mathrm{lb} / \mathrm{mi}^{2}\right)$ & 0.17514 & kilograms per square kilometer $\left(\mathrm{kg} / \mathrm{km}^{2}\right)$ \\
\hline $\begin{array}{l}\text { pounds per square mile per year } \\
\qquad\left(\left(\mathrm{lb} / \mathrm{mi}^{2}\right) / \mathrm{yr}\right)\end{array}$ & 0.17514 & $\begin{array}{l}\text { kilograms per square kilometer per year } \\
\qquad\left(\left(\mathrm{kg} / \mathrm{km}^{2}\right) / \mathrm{yr}\right)\end{array}$ \\
\hline $\begin{array}{l}\text { pounds per year per square mile } \\
\left((\mathrm{lb} / \mathrm{yr}) / \mathrm{mi}^{2}\right)\end{array}$ & 0.17514 & $\begin{array}{l}\text { kilograms per year per square kilometer } \\
\left((\mathrm{kg} / \mathrm{yr}) / \mathrm{km}^{2}\right)\end{array}$ \\
\hline
\end{tabular}

Temperature in degrees Celsius $\left({ }^{\circ} \mathrm{C}\right)$ may be converted to degrees Fahrenheit $\left({ }^{\circ} \mathrm{F}\right)$ as follows:

${ }^{\circ} \mathrm{F}=\left(1.8 x^{\circ} \mathrm{C}\right)+32$

Concentrations of chemical constituents in water are given either in milligrams per liter ( $\mathrm{mg} / \mathrm{L}$ ) or micrograms per liter $(\mu \mathrm{g} / \mathrm{L})$. 
Abbreviations

AIC - Akaike Information Criterion

EDI - equal-discharge increment

EWI - equal-width increment

$\mathrm{mL}$ - milliliter

MCL - maximum contaminant level

$\mathrm{N}$ - normal

NADP - National Atmospheric Deposition Program

NPDES - National Pollutant Discharge Elimination System

NWOL - National Water Quality Laboratory

PCS - Permit Compliance Section

RPD - relative percent difference

TMDL - total maximum daily load

USEPA - U.S. Environmental Protection Agency

USGS - U.S. Geological Survey 


\title{
Concentrations, and Estimated Loads and Yields of Nutrients and Suspended Sediment in the Little River Basin, Kentucky, 2003-04
}

\author{
By Angela S. Crain
}

\section{Abstract}

Nutrients, primarily nitrogen and phosphorus compounds, naturally occur but also are applied to land in the form of commercial fertilizers and livestock waste to enhance plant growth. Concentrations, estimated loads and yields, and sources of nitrite plus nitrate, total phosphorus, and orthophosphate were evaluated in streams of the Little River Basin to assist the Commonwealth of Kentucky in developing "total maximum daily loads" (TMDLs) for streams in the basin. The Little River Basin encompasses about 600 square miles in Christian and Trigg Counties, and a portion of Caldwell County in western Kentucky. Water samples were collected in streams in the Little River Basin during 2003-04 as part of a study conducted in cooperation with the Kentucky Department of Agriculture. A total of 92 water samples were collected at four fixed-network sites from March through November 2003 and from February through November 2004. An additional 20 samples were collected at five synoptic-network sites during the same period.

Median concentrations of nitrogen, phosphorus, and suspended sediment varied spatially and seasonally. Concentrations of nitrogen were higher in the spring (March-May) after fertilizer application and runoff. The highest concentration of nitrite plus nitrate—5.7 milligrams per liter ( $\mathrm{mg} / \mathrm{L})$ - was detected at the South Fork Little River site. The Sinking Fork near Cadiz site had the highest median concentration of nitrite plus nitrate $(4.6 \mathrm{mg} / \mathrm{L})$.

The North Fork Little River site and the Little River near Cadiz site had higher concentrations of orthophosphate in the fall and lower concentrations in the spring. Concentrations of orthophosphate remained high during the summer (JuneAugust) at the North Fork Little River site possibly because of the contribution of wastewater effluent to streamflow. Fiftyeight percent of the concentrations of total phosphorus at the nine sites exceeded the U.S. Environmental Protection Agency recommended maximum concentration limit of $0.1 \mathrm{mg} / \mathrm{L}$.
Concentrations of suspended sediment were highest in the spring during runoff and lowest in the fall. The highest concentration of suspended sediment $(1,020 \mathrm{mg} / \mathrm{L})$ was observed at the Sinking Fork near Cadiz site. The median concentration of suspended sediment for all sites sampled was $12 \mathrm{mg} / \mathrm{L}$. A nonparameteric statistical test (Wilcoxson ranksum) showed that the median concentrations of suspended sediment were not different among any of the fixed-network sites.

The Little River near Cadiz site contributed larger estimated mean annual loads of nitrite plus nitrate $(2,500,000$ pounds per year $(\mathrm{lb} / \mathrm{yr}))$ and total phosphorus $(160,000 \mathrm{lb} / \mathrm{yr})$ than the other three fixed-network sites. Of the two main upstream tributaries from the Little River near Cadiz site, the North Fork Little River was the greatest contributor of total phosphorus to the study area with an estimated mean annual load of 107,000 lb/yr or about 64 percent of the total estimated mean annual load at the Little River near Cadiz site. The other main upstream tributary, South Fork Little River, had an estimated mean annual load of total phosphorus that was about 20 percent of the mean annual load at the Little River near Cadiz site. Estimated loads of suspended sediment were largest at the Little River near Cadiz site, where the estimated mean annual load for 2003-04 was about $84,000,000 \mathrm{lb} / \mathrm{yr}$. The North Fork Little River contributed an estimated 36 percent of the mean annual load of suspended sediment at the Little River near Cadiz site, while the South Fork Little River contributed an estimated 18 percent of the mean annual load at the Little River near Cadiz site.

The North Fork Little River site had the largest estimated mean annual yield of total phosphorus (1,600 pounds per year per square mile $\left.\left(\mathrm{lb} / \mathrm{yr} / \mathrm{mi}^{2}\right)\right)$ and orthophosphate $\left(1,100 \mathrm{lb} / \mathrm{yr} / \mathrm{mi}^{2}\right)$. A principal source of phosphorus for the North Fork Little River is discharge from wastewater-treatment facilities. The largest estimated mean annual yield of nitrite plus nitrate was observed at the South Fork Little River site. The North Fork Little River site had the largest estimated mean annual yield of suspended sediment $\left(450,000 \mathrm{lb} / \mathrm{yr} / \mathrm{mi}^{2}\right)$. 
Inputs of nitrogen and phosphorus to streams from point and nonpoint sources were estimated for the Little River Basin. Commercial fertilizer and livestock-waste applications on row crops are a principal source of nutrients for most of the Little River Basin. Sources of nutrients in the urban areas of the basin mainly are from effluent discharge from wastewatertreatment facilities and fertilizer applications to lawns and golf courses.

\section{Introduction}

Nitrogen and phosphorus are essential nutrients for the growth of plants and animals. Nitrogen and phosphorus compounds occur naturally, but also are applied to land in the form of commercial fertilizers and livestock waste to enhance plant growth. Nutrients that are not utilized by crops or stored in the soil can travel in runoff to streams or through soil to ground water. Suspended sediment plays a major role in the transport and fate of contaminants because contaminants may sorb onto the surface of the suspended sediments and be transported and deposited in other areas downstream. Concentrations of suspended sediment are affected by natural conditions (soil erosion, streambed resuspension) and by human activities (construction, timber harvesting, and certain agricultural practices).

Excess nutrients and suspended sediment in the environment can be detrimental to aquatic ecosystems and to the health of organisms living in and using water. Section 303(d) of the Clean Water Act requires that each State identify surface waters that do not meet applicable water-quality standards. In Kentucky, about 520 stream miles are impaired because of nutrients and about 470 stream miles are impaired because of suspended sediment (U.S. Environmental Protection Agency, 2006a). The Kentucky Environmental and Public Protection Cabinet-Division of Water has listed some streams in the Little River Basin (fig. 1) as impaired streams for nutrients and suspended sediment in the State's 2002 305(b) Report to Congress on Water Quality and in the 2002 and 2004 303(d) List of Waters for Kentucky report (Kentucky Environmental and Public Protection Cabinet, 2002, 2003, and 2005). The State must develop plans to restore and maintain the water quality of the streams in the Little River Basin because of these impairments. The plans establish a "total maximum daily load" (TMDL) for the impaired streams. A TMDL represents the total amount of contaminant a water body can assimilate without violating the designated water-quality standard established by the U.S. Environmental Protection Agency (USEPA). The State currently (2006) is developing TMDLs specifically for the North Fork Little River and the South Fork Little River.

In 2003, the U.S. Geological Survey (USGS), in cooperation with the Kentucky Department of Agriculture, began a study to determine concentrations and estimate loads and yields of nutrients and suspended sediment in the Little River Basin. Information from this study will assist State and local water managers and planners, who are responsible for implementing TMDLs for streams in the Little River Basin to make informed management decisions on nutrients and suspended sediment. The purpose of the study was to determine the presence and distribution of nutrients and suspended sediment in streams in the Little River Basin study area and to estimate loads and yields of nutrients and suspended sediment at selected sites in the basin. Pesticides and pesticide degradates also were collected during this study and their results can be found in Crain (2006).

\section{Purpose and Scope}

This report summarizes the occurrence and distribution of nutrients and suspended sediment and provides estimates of nutrient and suspended-sediment loads and yields from samples collected from streams in the Little River Basin during 2003-04. The spatial and seasonal variability in concentrations of nutrients and suspended sediment is presented. Nutrient and suspended-sediment loads are computed using LOADEST, a USGS software program used to compute mean constituent loads in rivers using regression models. Estimated loads and yields of nutrients and suspended sediment are presented for three sites in the basin.

\section{Description of the Little River Basin}

The Little River Basin encompasses about $600 \mathrm{mi}^{2}$ (fig. 1). The Little River discharges into Lake Barkley Reservoir on the Cumberland River. Water quality throughout the basin is directly affected by natural (geology, climate, soils) and human (population, land use) factors. The Little River Basin has a high "hydrogeologic sensitivity rating" indicating it is highly vulnerable to effects from runoff, because much of the area is underlain by karst (Ray and others, 1994). The hydrologic sensitivity of an area is defined as the ease and speed with which a contaminant is transported within a ground-water system (Ray and others, 1994). Some streams in the Little River Basin are listed as impaired streams in the State's 303(d) List of Waters for Kentucky report (Kentucky Environmental and Public Protection Cabinet, 2005). The Kentucky Division of Water has listed the causes of impairments to the streams in the basin as siltation, nutrients, pathogens, organic enrichment (low dissolved oxygen), and habitat alterations (Kentucky Environmental and Public Protection Cabinet, 2005, p. 134-136). 


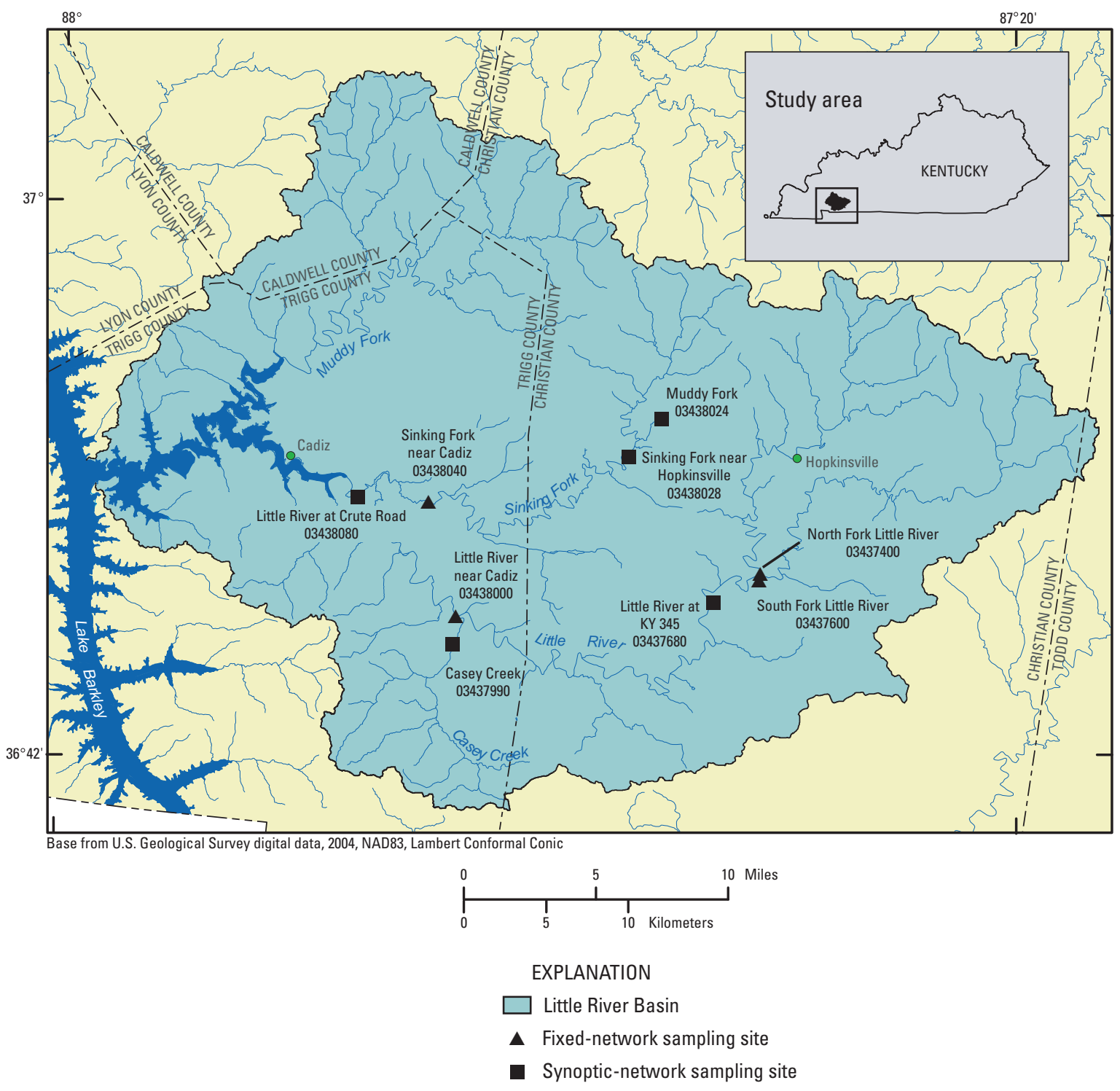

Figure 1. Location of the surface-water-sampling sites in the Little River Basin, Kentucky, 2003-04. 


\section{Geology}

The Little River Basin mostly is underlain by karstic limestone formations of late Mississippian age (fig. 2). The limestone units of significance within the Little River Basin study area are the St. Louis and Ste. Genevieve Limestone. The St. Louis Limestone mostly is composed of sequences of massively bedded (tabular) limestones, and the Ste. Genevieve Limestone mostly is composed of thin-bedded, cherty limestones.

Overlying the Ste. Genevieve and St. Louis Limestone on the northeastern side of the study area is a thick sequence of limestone, sandstone, and shale formations of Chesterian age (late Mississippian) that are divided into upper and lower parts. The lower Chesterian is composed of alternating sandstone and limestone strata that includes the Golconda
Formation (sandstone dominated) and the Girkin Limestone (McDowell, 1986). The upper rocks of the Chesterian-age formations are mainly composed of siltstone and shale with alternating minor beds of limestone.

Numerous karst features including sinkholes (fig. 3), sinking streams, and springs are present in the study area. The exposure of Ste. Genevieve Limestone at the land surface allows for water from surface-water streams to enter the underground cavities through sinkholes. Water also enters the Ste. Genevieve and Girkin Limestones through sinkholes developed in the sandstone members of the Golconda Formation. Potential contaminants may enter the karstic limestone aquifers with surface runoff drained by sinkholes in the St. Louis and Ste. Genevieve Limestone and through sinking streams.

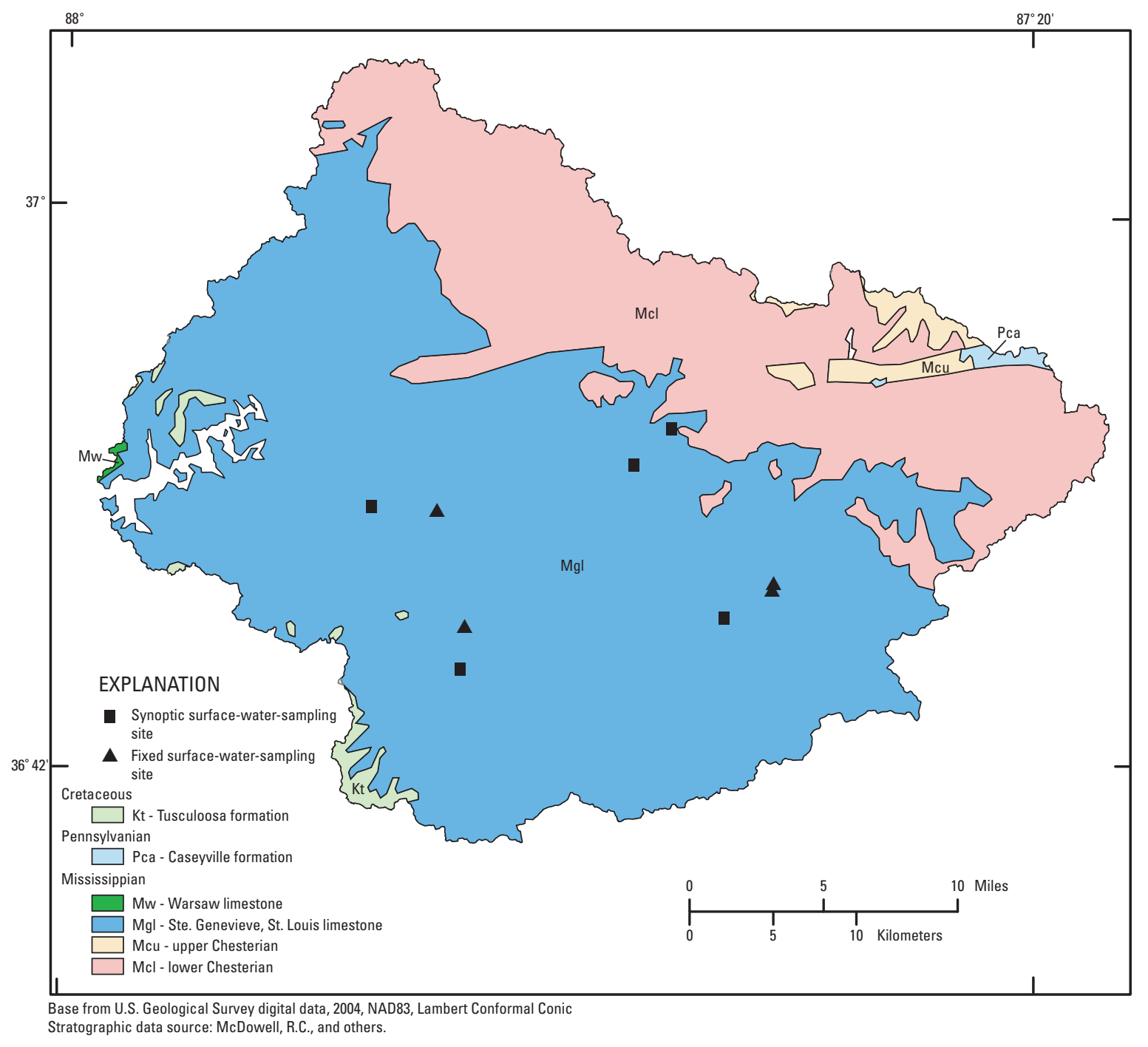

Figure 2. Surficial geology in the Little River Basin, Kentucky, 2003-04. 


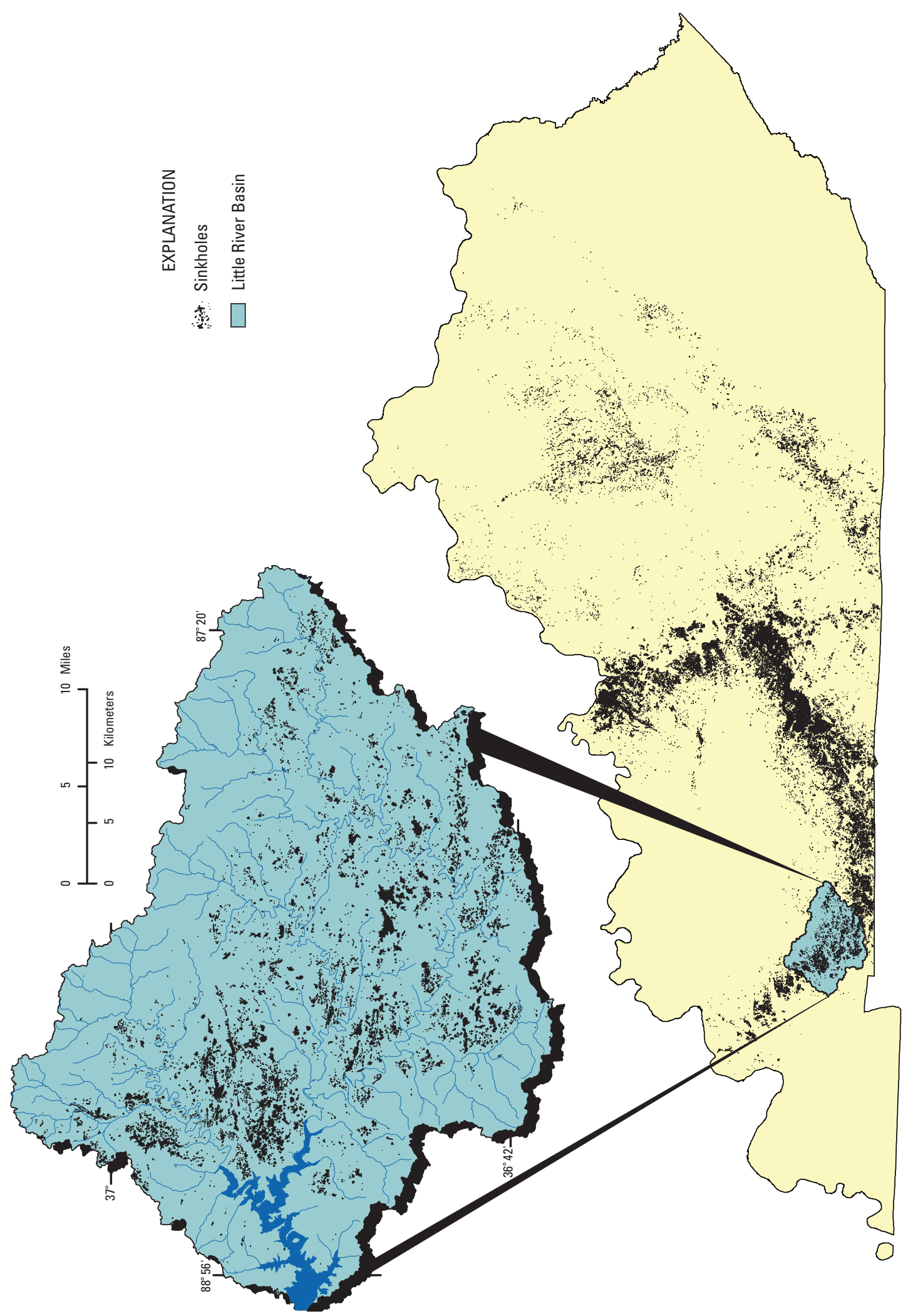

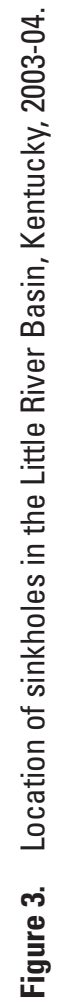




\section{Streamflow}

Direct surface runoff and ground-water discharge are the major sources of streamflow in the Little River Basin. Another source is interflow, which is part of the subsurface flow that moves at shallow depths and potentially can reach the surface channels in a short period of time. During a storm, interflow slowly increases until the end of the storm, then gradually decreases (Viessman and others, 1989, p. 171).

Annual mean flow differs appreciably from year to year, with variations in weather conditions. Mean annual streamflow of the Little River near Cadiz site (water years 1940-2004) was about $360 \mathrm{ft}^{3} / \mathrm{s}$. It was $479 \mathrm{ft}^{3} / \mathrm{s}$ in 2003 and $299 \mathrm{ft}^{3} / \mathrm{s}$ in 2004 . Mean monthly streamflow usually peaks in the spring (MarchMay); however, there is often a second peak in the winter (December-February). Low streamflow conditions typically occur from late summer (June-August) to early fall (September-November). The mean daily streamflows for the Little River near Cadiz site in 2003 ranged from $27 \mathrm{ft}^{3} / \mathrm{s}$ (November 7) to $5,170 \mathrm{ft}^{3} / \mathrm{s}$ (May 7); mean daily streamflows in 2004 ranged from $33 \mathrm{ft}^{3} / \mathrm{s}$ (October 11) to 2,670 $\mathrm{ft}^{3} / \mathrm{s}$ (April 24).

Mean annual precipitation for the Little River Basin was 55.8 in. in 2003 and 54.0 in. in 2004 (National Oceanic and Atmospheric Administration, 2003 and 2004). About 63 percent of the mean annual precipitation in 2003 (34.9 in.) and about 57 percent of the mean annual precipitation in 2004 (31.0 in.) occurred during the growing season from April through October (fig. 4). The long-term mean annual precipitation for the Little River Basin is about 50 in.

\section{Land Use}

Streams in the Little River Basin drain a diverse landscape of forest, agricultural areas, and urban areas around Hopkinsville and Cadiz, Kentucky. Forested land represents about 31 percent of the Little River Basin. The southern and western parts are the most densely forested areas in the basin.

Agricultural land uses represent about 60 percent of the study area (fig. 5). Most of the agricultural land (34 percent) is used for corn, soybeans, wheat, hay, and tobacco production; the remaining 26 percent is used for pasture. Corn is the principal row crop harvested in the basin, followed by soybeans. In 2003, about 95,000 acres of corn were harvested for seed, grain, silage, or sweet corn; about 76,500 acres were harvested for soybeans (Kentucky Agricultural Statistics Service, 2004).

Urban areas represent about 9 percent of the land use in the basin. The most heavily populated communities in the Little River Basin are Hopkinsville and Cadiz. Hopkinsville has a population of about 30,000; Cadiz has a population of about 2,400 (U.S. Census Bureau, 2002).

\section{Study Design and Methods}

Stream-sampling sites in the Little River Basin were selected to assess the spatial and seasonal variability of nutrients and suspended sediment in subbasins consisting of mixed land use and different types of agricultural land. Samples were collected on three Little River main-stem sites and five tributaries - the North Fork Little River, South Fork Little River, Muddy Fork, Sinking Fork, and Casey Creek (fig. 1 and table 1).

\section{Sample-Site Selection and Sampling Frequency}

Water-quality and suspended-sediment samples were collected monthly (March 2003 through November 2003 and February 2004 through November 2004) at four fixed-network sites. The sites included North Fork Little River, South Fork Little River, Sinking Fork near Cadiz, and Little River near Cadiz. These sites were sampled to monitor seasonal changes in water quality resulting from a variety of land-use activities. An additional four samples were collected at each of these sites for three high-flow events and one low-flow event.

In addition to the routine sampling at the four fixed-network sites, five synoptic-network sites were sampled twice each year in 2003 and 2004. The sites included Little River at KY 345, Muddy Fork, Sinking Creek near Hopkinsville, Casey Creek, and Little River at Crute Road. A total of three high-flow events and one low-flow event were collected over the 2 years to evaluate the spatial distribution of nutrients and suspended sediment in the Little River Basin.

Ninety-two samples were collected for nutrient and suspended sediment at the fixed-network sites, and 20 samples were collected at the synoptic-network sites. Twenty-two samples were collected for quality assurance/quality control (blanks and replicates).

\section{Sampling Methods}

Representative water samples were collected by means of the equal-width increment (EWI) method, in which depthintegrated samples are collected at equal distances across the entire stream width and composited, or by means of the equal-discharge increment (EDI) method, in which equal-volume, depth-integrated samples are collected at the center of each EDI across the stream width and composited (Edwards and Glysson, 1998). All sampling material was constructed of Teflon to minimize contamination. Equipment used to collect and process nutrient samples was pre-cleaned with a 0.1 -percent nonphosphate detergent, triple rinsed with tap water, acid rinsed with 5-percent hydrochloric acid for 30 minutes (nonmetal equipment only), triple rinsed with deionized water, air dried, and stored in a dust-free environment prior to sample collection (Webb and others, 1999). 


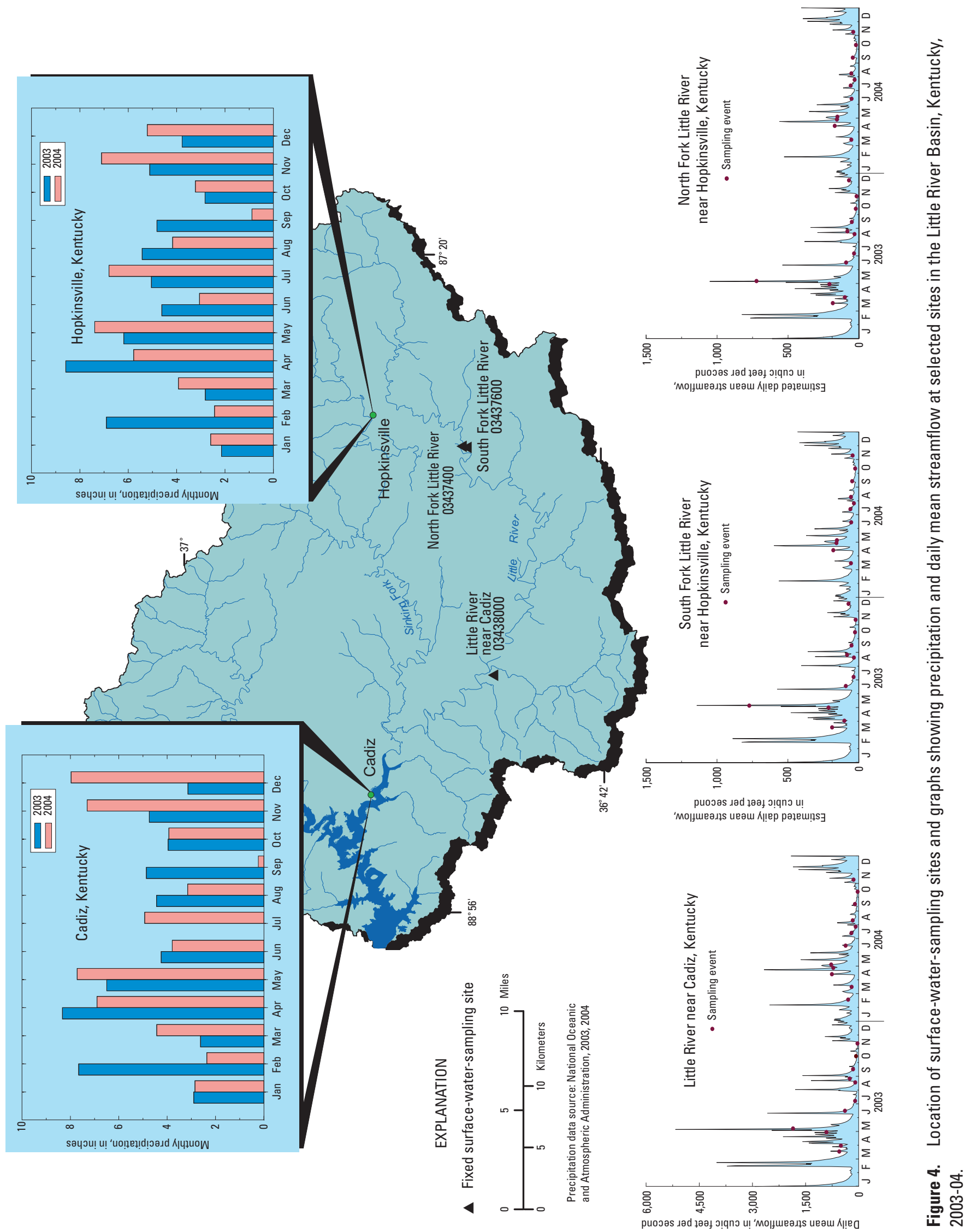




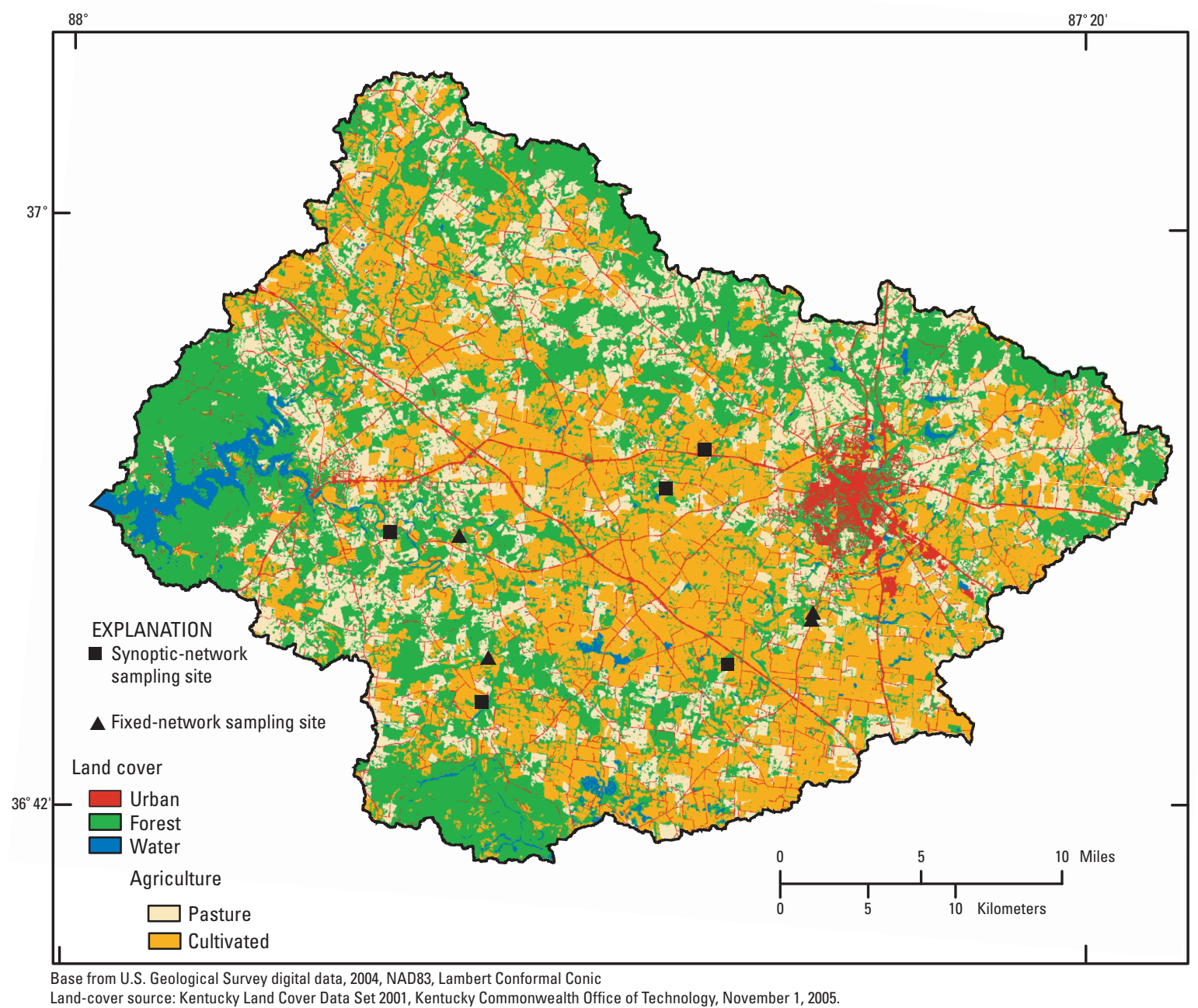

Figure 5. Land cover in the Little River Basin, Kentucky, 2001.

Water samples for dissolved nutrients were filtered using a 0.45 -micrometer $(\mu \mathrm{m})$ pore-size filter that was pre-rinsed with deionized water and filtered native stream water and collected in the appropriate bottle types. Whole-water (unfiltered) nutrient samples were preserved using 1 milliliter $(\mathrm{mL})$ of $4.5 \mathrm{~N}$ sulfuric acid. All nutrient samples were chilled and shipped on ice by overnight air express to the USGS National Water Quality Laboratory (NWQL) in Lakewood, Colorado, for analysis. Suspended-sediment samples were shipped to the USGS Kentucky Water Science Center Sediment Laboratory in Louisville, Kentucky.

Field measurements of stream discharge, air temperature, barometric pressure, water temperature, specific conductance, $\mathrm{pH}$, concentrations of dissolved oxygen (DO), and turbidity were measured at the time of sampling. Alkalinity and concentrations of bicarbonate were determined by titrating filtered sample water with $0.16 \mathrm{~N}$ sulfuric acid using a digital titrator. Discharge was measured according to standard USGS guidelines as described by Rantz and others (1982). The field measurement data is available online at $h t t p: / / k y$.water.usgs. gov/.

A continuously recording (15-minute interval) waterquality monitor was installed at the USGS streamflow-gaging station on Little River near Cadiz, Kentucky (station number 03438000), on April 1, 2003. Water-quality properties measured with the monitor during April 2003-November 2004 included water temperature, specific conductance, $\mathrm{pH}$, dissolved oxygen, and turbidity. Measurements were transmitted every 4 hours via satellite to the USGS office in Louisville, Kentucky, and were made available in near-real time on the Internet at URL http//ky.water.usgs.gov/. The water-quality monitor was inspected onsite by USGS personnel approximately every 3 to 4 weeks to maintain calibration. Guidelines and standard operating procedures for maintaining the site and reporting the data are described in Wagner and others (2000). 
Table 1. Description of surface-water-sampling sites in the Little River Basin, Kentucky, 2003-04.

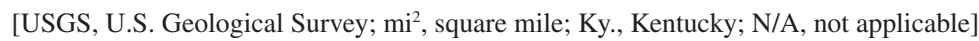

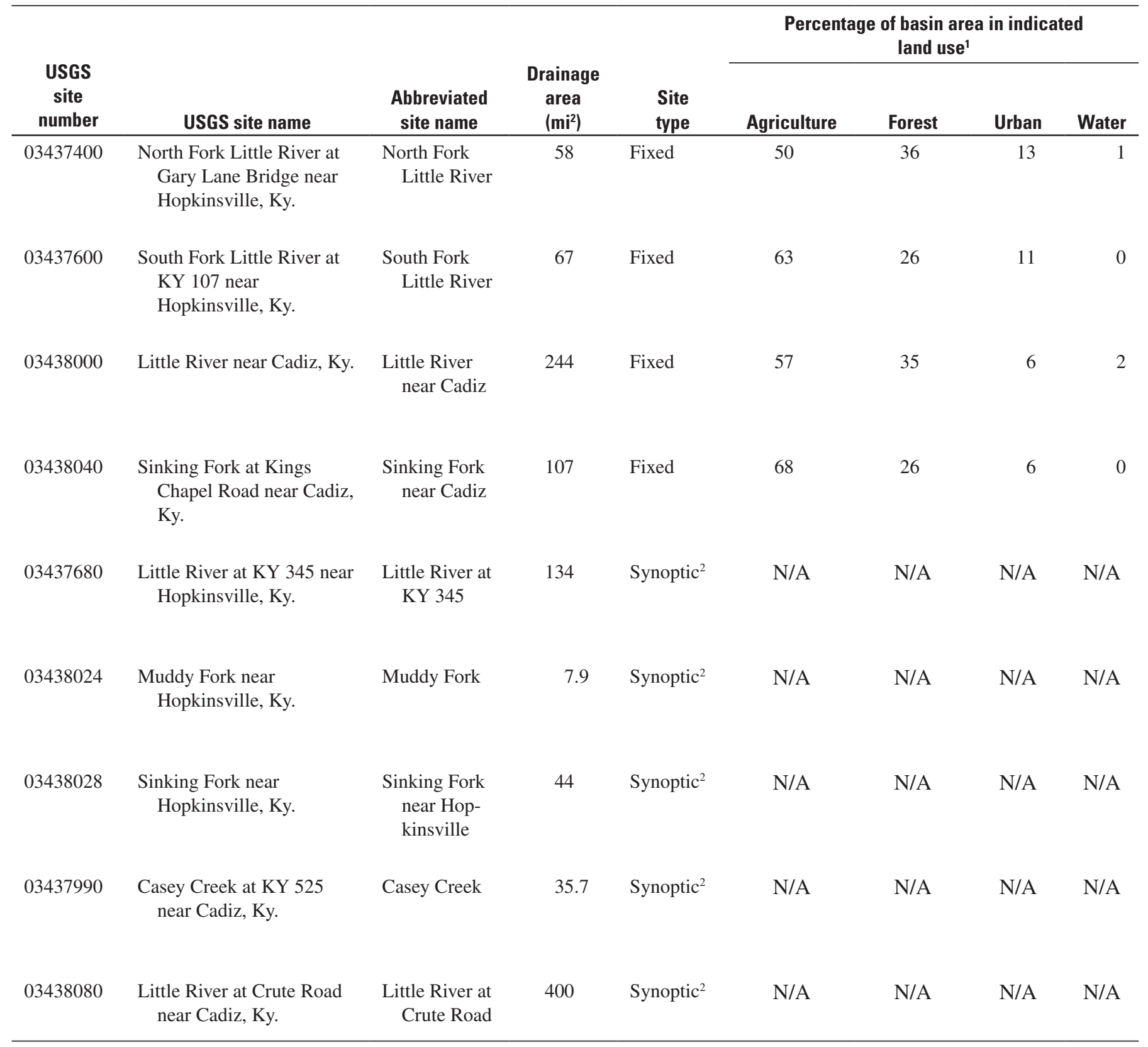

${ }^{1}$ Kentucky Land Cover Data Set, 2001, Kentucky Commonwealth Office of Technology, November 1, 2005.

${ }^{2}$ Site located within the 10-digit hydrologic-unit code of one of the four fixed-network sites. 


\section{Analytical Methods}

The USGS NWQL analyzed the water-quality samples for nutrients. Water-quality samples for dissolved (filtered) and suspended (unfiltered) species of nitrogen and phosphorus were analyzed by colorimetric methods (Fishman, 1993; Patton and Truitt, 1992; Patton and Kryskalla, 2003; U.S. Environmental Protection Agency, 1993). These analyses quantified sample concentrations of dissolved nitrite plus nitrate, dissolved ammonia nitrogen, dissolved orthophosphate, and total phosphorus (table 2). Concentrations of nutrients discussed in this report represent their concentrations expressed as either nitrogen or phosphorus. For example, a concentration of nitrite plus nitrate expressed as 10 milligrams per liter $(\mathrm{mg} / \mathrm{L})$ refers to a concentration of nitrite plus nitrate of $10 \mathrm{mg} / \mathrm{L}$ as nitrogen.

The USGS Kentucky Water Science Center in Louisville, Kentucky, analyzed the suspended-sediment samples by filtering samples through a pretared $0.45-\mu \mathrm{m}$ membrane filter. The filtrate was rinsed with deionized water to remove salts, and the insoluble material and filter were dried at $103^{\circ} \mathrm{C}$ and weighed (Fishman and Friedman, 1989).

Table 2. Reporting limits for nutrients as established by the U.S. Geological Survey National Water-Quality Laboratory.

[mg/L, milligrams per liter; $\mathrm{N}$, nitrogen; $\mathrm{P}$, phosphorus]

\section{Constituent}

\section{Laboratory reporting level}

$\begin{array}{lc}\text { Ammonia (as N), dissolved } & 0.04 \mathrm{mg} / \mathrm{L} \text { as N } \\ \begin{array}{l}\text { Nitrite plus nitrate (as N), } \\ \text { dissolved }\end{array} & .06 \mathrm{mg} / \mathrm{L} \text { as N } \\ \text { Phosphorus (as P), total } & .004 \mathrm{mg} / \mathrm{L} \text { as P } \\ \begin{array}{l}\text { Orthophosphate (as P), } \\ \text { dissolved }\end{array} & .006 \mathrm{mg} / \mathrm{L} \text { as P }\end{array}$

\section{Quality Control}

Quality-control information is needed to estimate the bias and variability that result from sample collection, sample processing, and laboratory analysis in order to ensure proper interpretation of water-quality data. About 20 percent of all samples submitted to the laboratory were quality-control samples, which included equipment blanks and field blanks to measure contamination and bias, and replicate samples to measure variability.

A blank is a water sample that consists of water that has undetectable concentrations of analytes of interest. Blankwater samples are used to test for bias that could result from contamination during any stage of sample collection or analysis process. Field-blank samples were collected to demonstrate that (1) equipment has been adequately cleaned to remove contamination introduced by samples obtained at previous sites; (2) sample collection and processing have not resulted in contamination; and (3) sample handling, transport, and laboratory analysis have not introduced contamination (Mueller and others, 1997). The procedure for blank samples was to use pesticide-free water through all of the sampling and filtration steps as a typical water-quality sample. Field-blank sample concentrations for nutrients did not indicate any contamination from the equipment or sample-processing methods.

Replicate samples are a set of two or more environmental samples considered to be essentially identical in composition. Concurrent replicates are prepared by using one sampler and alternating collection of the samples into two or more compositing containers. All replicates collected in the Little River Basin were concurrent replicates.

Data obtained from the six sets of replicate samples were used to access the variability of the overall sampling and analytical process. Replicate samples were compared by using relative percent differences (RPDs). RPD's for each analyte and replicate sample pair was calculated by the following equation:

$$
R P D=|S 1-S 2| /(S 1+S 2) / 2 \times 100
$$

where

S1 is equal to the concentration in the environmental sample, in $\mathrm{mg} / \mathrm{L}$ (nutrients and suspended sediment); and

S2 is equal to the concentration in the replicate sample, in $\mathrm{mg} / \mathrm{L}$ (nutrients and suspended sediment).

The larger the RPD, the greater the variability in those samples. Concentration differences, as measured by RPD, within replicate sets ranged from 0 to 5 percent for nutrients and were 15 percent for suspended sediment (table 3 ). If the RPD of replicate samples was 15 percent or less, then the data from the collected samples were determined to meet the precision objectives of the project.

\section{Statistical Analysis of Nutrients and Suspended Sediment}

The S-Plus software program (Insightful, 2005) was used to calculate summary statistics such as the mean, median, minimum, and maximum concentrations for nutrients and suspended sediment (Appendix 1). The Wilcoxson rank-sum nonparameteric statistical test (Helsel and Hirsch, 1992) was used to compare concentrations of nutrients and suspended sediment at the four fixed-network sites in the basin. The Wilcoxson rank-sum tests rank the data points to determine the statistical significance of differences in concentrations among groups of data. Differences among the groups of data with probability $(p)$ values of 0.05 or less were considered significant in this study. 
Table 3. Summary of replicate-sample data for nutrients and suspended sediment in the Little River Basin, Kentucky, 2003-04.

[RPD, relative percent difference; $<$, less than]

\begin{tabular}{|c|c|c|c|}
\hline Constituent & $\begin{array}{c}\text { Number of } \\
\text { replicate } \\
\text { sample sets }\end{array}$ & Median RPD & Maximum RPD \\
\hline Ammonia (as N), dissolved & 6 & 0 & $<1$ \\
\hline $\begin{array}{l}\text { Nitrite plus nitrate (as N), } \\
\text { dissolved }\end{array}$ & 6 & .14 & 2 \\
\hline Phosphorus (as P), total & 6 & .94 & 5 \\
\hline $\begin{array}{l}\text { Orthophosphate (as P), } \\
\text { dissolved }\end{array}$ & 6 & 1.1 & 3 \\
\hline Suspended sediment & 5 & 0 & 15 \\
\hline
\end{tabular}

\section{Load-Estimation Methods}

Nutrient (ammonia nitrogen, nitrite plus nitrate, total phosphorus, and orthophosphate) loads and suspended sediment loads were estimated with the USGS software, LOADEST. This software uses time-series streamflow data and constituent concentrations to calibrate a regression model that describes constituent loads in terms of various functions of streamflow and time (Runkel and others, 2004). A complete discussion of the theory and principles behind the calibration and estimation methods can be found in Runkel and others (2004).

The LOADEST software allows the user to choose between selecting the general form of the regression from several predefined models and letting the software automatically select the best-defined model, on the basis of the Akaike Information Criterion (AIC) (Akaike, 1981). The predefined model with the lowest value for the AIC was then selected for use in load estimation. A user-defined model was used for this study. User-defined results and results defined by the software are listed in table 4. The RPD's between the two methods ranged from about 0 to 14 percent (table 4).

The output regression equations have the following general form:

$$
\begin{aligned}
\ln (L)= & a+b(\ln Q)+c\left(\ln Q^{2}\right)+d[\sin (2 \pi T)] \\
& +e[\cos (2 \pi T)]+f T+g T^{2}
\end{aligned}
$$

where

$L \quad$ is the constituent load, in $\mathrm{lb} / \mathrm{d}$;

$Q \quad$ is the stream discharge, in $\mathrm{ft}^{3} / \mathrm{s}$;

$T$ is the time, in decimal years, from the beginning of the calibration period; and $a, b, c, d, e, f, g$ are regression coefficients.

\section{Sources of Nitrogen and Phosphorus}

Sources of nutrients into the Little River Basin are categorized as nonpoint or point source. Contaminant sources that are diffuse and do not have a single point of origin into receiving streams are called nonpoint sources. Nonpoint sources of nutrients include atmospheric deposition, fertilizer applications from agricultural and residential areas, feed-lot discharges, septic systems, and urban runoff. Point sources differ from nonpoint sources in that they discharge directly into a receiving stream at a discrete point. Point sources primarily consist of a variety of large and small wastewater-treatment facilities, but nutrient inputs also can come from storm-water runoff and sewer overflows.

\section{Nonpoint-Source Contributions}

Nonpoint-source inputs of nutrients for the Little River Basin estimated in this report include atmospheric deposition, commercial fertilizer application, livestock waste, and nitrogen fixation from soybeans (table 5). Nutrient inputs from urban runoff, combined sewer overflows, and septic systems were not included in the nonpoint source estimates of this report because of minimal or no data. 
Table 4. Loads of nutrients and suspended sediment at three sites in the Little River Basin, Kentucky, 2003-04, using LOADEST predefined and user-defined models.

[lb/yr, pound per year; ---, unable to determine from available data]

\begin{tabular}{cccc}
\hline & Predefined & User-defined & \\
& LOADEST & LOADEST model & Relative \\
& model results & results & difference \\
Constituent & (lb/yr) & (lb/yr) & (in percent) \\
\hline
\end{tabular}

North Fork Little River near Hopkinsville, Ky. (03437400)

$\begin{array}{lccr}\text { Ammonia as (N), dissolved } & 13,000 & 13,000 & 0 \\ \text { Nitrite plus nitrate as (N), dissolved } & 470,000 & 450,000 & 4.3 \\ \text { Phosphorus as (P), total } & 105,000 & 107,000 & 1.9 \\ \text { Orthophosphate as (P), dissolved } & 75,000 & 74,000 & 1.3 \\ \text { Suspended sediment } & 26,000,000 & 30,000,000 & 14\end{array}$

South Fork Little River near Hopkinsville, Ky. (03437600)

Ammonia as $(\mathrm{N})$, dissolved

Nitrite plus nitrate as $(\mathrm{N})$, dissolved

803,000

780,000

4.6

Phosphorus as $(\mathrm{P})$, total

28,000

32,000

13

Orthophosphate as $(\mathrm{P})$, dissolved

13,000

14,000

7.4

Suspended sediment

$18,000,000$

$18,000,000$

0

Little River near Cadiz, Ky. (03438000)

Ammonia as (N), dissolved

Nitrite plus nitrate as $(\mathrm{N})$, dissolved

$2,700,000$

$2,500,000$

5.6

Phosphorus as (P), total

145,000

166,000

13

Orthophosphate as (P), dissolved

59,000

65,000

9.7

Suspended sediment

$91,000,000$

$84,000,000$

8.0 
Table 5. Estimated mean annual loads of total nitrogen and total phosphorus from nonpoint and point sources in the Little River Basin, Kentucky, 2003-04.

[lb/yr, pound per year; NA, not applicable]

\begin{tabular}{lcc}
\hline \multicolumn{1}{c}{ Constituent } & $\begin{array}{c}\text { Mean annual } \\
\text { load of total } \\
\text { nitrogen } \\
(\mathbf{l b} / \mathbf{y r})\end{array}$ & $\begin{array}{c}\text { Mean annual } \\
\text { load of total } \\
\text { phosphorus } \\
(\mathbf{l b} / \mathbf{y r})\end{array}$ \\
\hline $\begin{array}{c}\text { Atmospheric } \\
\text { deposition }\end{array}$ & Inputs to land & \\
Farm fertilizer $^{3}$ & 2,600 & $\mathrm{NA}$ \\
Nonfarm fertilizer $^{3}$ & $9,800,000$ & $2,100,000$ \\
Livestock waste $^{1}$ & 68,000 & 4,000 \\
Nitrogen fixation $^{4}$ & $3,000,000$ & $1,000,000$ \\
& 20,000 & $\mathrm{NA}$ \\
Municipal wastewater $_{\text {discharge }}$ & Input to streams & \\
\hline
\end{tabular}

${ }^{1}$ U.S. Department of Agriculture, 2004.

${ }^{2}$ Data from National Atmospheric Deposition Program, 2006. Dry deposition nitrogen not included in atmospheric deposition.

${ }^{3}$ Ruddy and others, 2006. Data from 2001.

${ }^{4}$ Kentucky Agricultural Statistics Service, 2004.

${ }^{5}$ U.S. Environmental Protection Agency, 2006b

\section{Atmospheric Deposition}

Atmospheric deposition of nitrogen has been measured since December 1994 at a site in the Land between the Lakes National Recreation Area (KY99) in Trigg County, Kentucky. The wet-deposition data from the National Atmospheric Deposition Program (NADP) include nitrate and ammonia. No dry deposition data are measured; therefore, total atmospheric deposition of nitrogen cannot be obtained. Atmospheric deposition of phosphorus is not measured by NADP because concentrations generally are not appreciable and samples are subject to contamination (National Atmospheric Deposition Program, 2006).

Rates of wet deposition of total nitrogen in 2003 and 2004 were 2,900 and 2,300 lb/ $\mathrm{mi}^{2}$, respectively. The 8 -year mean rate (1995-2004) of wet deposition of total nitrogen was $2,200 \mathrm{lb} / \mathrm{mi}^{2}$. The wet-deposition inputs for total nitrogen during 2003-04 were higher than the 8-year mean, reflecting above-average precipitation for those 2 years. The NADP provides annual-summary reports which are available online at http://nadp.sws.uiuc.edu/.

\section{Commercial Fertilizer and Livestock Waste}

Commercial fertilizers applied to agricultural lands has become a primary nonpoint source of nitrogen and phosphorus in the United States. Commercial nitrogen fertilizer is applied as either ammonia or nitrate and commercial phosphorus fertilizer commonly is applied as phosphate. Application of nitrogen and phosphorus in commercial fertilizers in the United States during 1945-2001 increased by about 22 and 3.6 percent, respectively (Ruddy and others, 2006).

County-level data for nitrogen and phosphorus from commercial fertilizer (farm and nonfarm) and livestock waste were compiled in a national data set (Ruddy and others, 2006). The methods for allocating data on State total fertilizer sales to individual counties and for estimating livestock-waste inputs from livestock populations are described in detail by Ruddy and others (2006). The use of county-level data has some limitations in its application, because fertilizer and livestock waste sources are not evenly distributed within counties. The use of county-level data generally is more applicable to large drainage basins that encompass entire counties than smaller drainage basins that encompass only parts of one or more counties. However, the study area encompasses large portions of Christian and Trigg Counties, which are mostly homogenous in land use. Thus, any introduced error from using estimates of farm fertilizer and livestock waste inputs should not be appreciable.

Farm-fertilizer inputs of nutrients in 2001 were 9,800,000 $\mathrm{lb}$ of nitrogen and 2,100,000 lb of phosphorus in Christian and Trigg Counties, which are average applications of about $8,100 \mathrm{lb} / \mathrm{mi}^{2} / \mathrm{yr}$ of nitrogen and $1,700 \mathrm{lb} / \mathrm{mi}^{2} / \mathrm{yr}$ of phosphorus. The amount of cultivated-agricultural land in the Little River Basin is about 34 percent, or about $200 \mathrm{mi}^{2}$. Nitrogen and phosphorus fertilizers generally are applied to corn in spring just before seeding. Livestock waste also can be used during this time. Nitrogen fertilizer is reapplied to corn fields 6 to 10 weeks after planting; phosphorus fertilizer is applied to corn and soybeans at the time of planting. Nitrogen and phosphorus fertilizers and livestock waste are applied in late summer through early fall for cool-season pasture, hay fields, and wheat fields (University of Kentucky, 2001).

Nonfarm-fertilizer inputs of nutrients in 2001 were $68,000 \mathrm{lb}$ of nitrogen and 14,000 lb of phosphorus in Christian and Trigg Counties. These applications average about $56 \mathrm{lb} / \mathrm{mi}^{2} / \mathrm{yr}$ of nitrogen and $12 \mathrm{lb} / \mathrm{mi}^{2} / \mathrm{yr}$ of phosphorus.

Nitrogen and phosphorus in livestock waste potentially can be a major source of nitrogen and phosphorus loads in streams draining agricultural areas. Animal-feeding operations and concentrated animal-feeding operations, which concentrate animals, feed, and waste on a small land area, have greater potential to contribute nutrients to surface runoff and ground water. Wastes produced by these operations may be applied to pasture land and crop land, becoming available for either crop uptake or losses to the environment. An animalfeeding operation in Kentucky is defined as a facility where animals are confined and fed for a total of 45 days or more in any 12-month period and where crops, vegetation forage 
growth, or post-harvest residues are not sustained over any portion of the facility in the normal growing season (Kentucky Environmental and Public Protection Cabinet, 2006). In order for an animal-feeding operation to be defined as a confined animal-feeding operation, the facility has more than 300 animal units confined and there is a discharge to the Waters of the Commonwealth, or if more than 1,000 head of beef cattle, 700 head of dairy cattle, 2,500 pigs, 25,000 broilers, or 82,000 laying hens or pullets are present at the facility. There are 11 animal-feeding operations and 0 confined animal-feeding operations within the southern portion of the Little River Basin as of July 2006 (James Seay, Kentucky Environmental and Public Protection Cabinet-Kentucky Division of Water, written commun., 2006).

In Kentucky, the average inputs of nutrients from livestock waste were $1,100,000 \mathrm{lb}$ of nitrogen and $320,000 \mathrm{lb}$ of phosphorus in 1997. In Christian and Trigg Counties, nutrient inputs from livestock waste in 1997 were 3,000,000 lb of nitrogen and 1,000,000 $\mathrm{lb}$ of phosphorus. These nutrient inputs average about $2,500 \mathrm{lb} / \mathrm{mi}^{2} / \mathrm{yr}$ of nitrogen and $830 \mathrm{lb} / \mathrm{mi}^{2} / \mathrm{yr}$ of phosphorus throughout the basin. Actual nitrogen inputs to the land probably were lower because of volatilization of ammonia from the waste and nitrification and de-nitrification.

Nutrient-input estimates from livestock waste were based on county-level livestock-population data collected by the U.S. Census Bureau during the Census of Agriculture. The method and assumptions used in Ruddy and others (2006) to estimate nitrogen and phosphorus content of livestock waste produced by the various types of livestock are described by Goolsby and others (1999). The livestock groups used to estimate nutrient inputs from livestock waste include beef cattle, dairy cows, hogs, and poultry.

\section{Nitrogen Fixation by Soybeans}

Nitrogen fixation by soybeans is an important source of nitrogen in the Little River Basin because of the large acreage of soybeans in the study area; however, the fixation of nitrogen from soybeans is not used in computations of nonpointsource inputs of nitrogen because little nitrogen is available to enter the surface and ground water. The amount of nitrogen produced by fixation from soybeans in the basin is based on the area of soybeans planted and an annual nitrogen fixation rate of $105 \mathrm{lb} / \mathrm{acre}$, as used by Hoos and others (1999) from Craig and Kuenzler (1983) for soybeans in the southeast. This rate was multiplied by 2003-04 harvested acres for soybeans (Kentucky Agricultural Statistics Service, 2004) to estimate the amount of fixed nitrogen. The estimated nitrogen fixation for the Little River Basin was 20,000 lb/mi²/yr.

\section{Point-Source Contributions}

The only point-source inputs of nitrogen and phosphorus estimated in this report are municipal-wastewater discharge (table 5). Only facilities with a mean flow greater than $0.1 \mathrm{Mgal} / \mathrm{d}$ were available for input computations for this study (table 6). The exclusion of minor privately owned discharge facilities $(<0.1 \mathrm{Mgal} / \mathrm{d})$ in the study area, if totaled, could be an appreciable source of nitrogen and phosphorus to the basin.

Table 6. Estimated mean annual loads of total nitrogen and total phosphorus from municipal wastewater discharge in the Little River Basin, Kentucky, 2003-04.

[Mgal/d, million gallons per day; lb/yr, pounds per year; WWTP, wastewater-treatment plant]

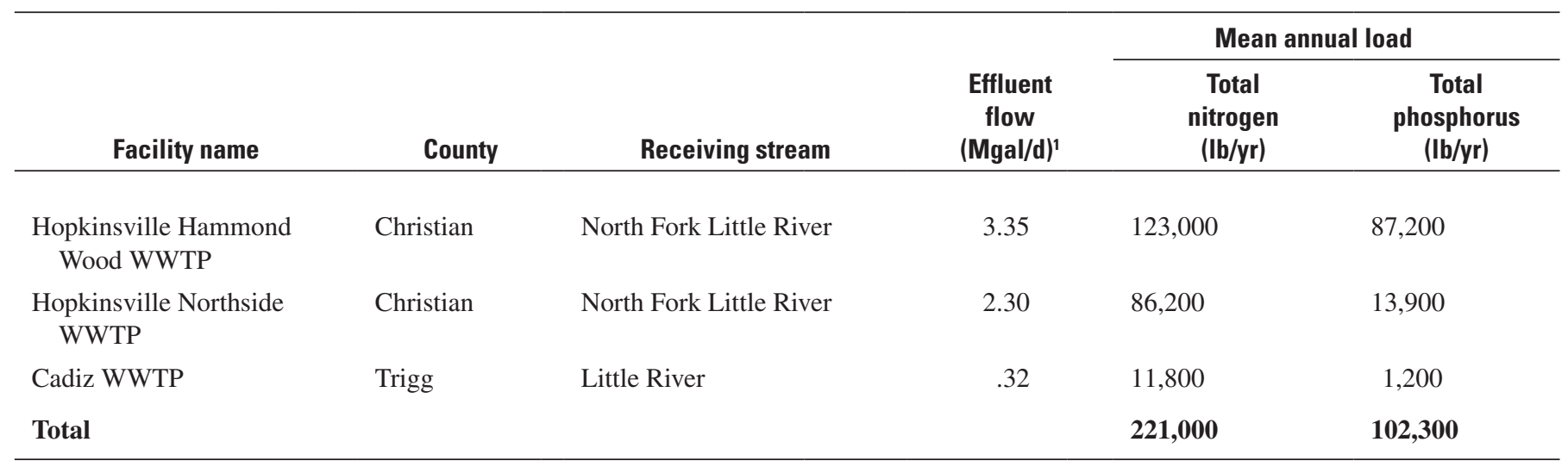

${ }^{1}$ U.S. Environmental Protection Agency, 2006b 
The nutrient inputs are based on information from the NPDES permitting program of the USEPA. The required monitoring data for NPDES discharges are stored in the USEPA's PCS database. All of the wastewater-treatment facilities in the Little River Basin monitor effluent for ammonia and total phosphorus, but concentrations of total nitrogen were not available. A regression equation, developed from more than 800 observations of effluent concentrations from municipal wastewater-treatment facilities in Virginia and North Carolina, was used to estimate concentrations of total nitrogen from concentrations of ammonia nitrogen (McMahon and Lloyd, 1995, p. 70-71). The regression equation is as follows:

$$
\text { Total nitrogen }=11.97+0.55(\text { ammonia })
$$

where concentrations are in $\mathrm{mg} / \mathrm{L}$, as nitrogen.

Nitrogen and phosphorus inputs to streams from municipal wastewater-treatment facilities were estimated using the following equation:

$$
L=(R Q)(C)(f)(T)
$$

where

$L \quad$ is nutrient load in lb/yr;

$R Q \quad$ is wastewater effluent flow in $\mathrm{ft}^{3} / \mathrm{s}$;

$C \quad$ is the mean concentration of nutrient in $\mathrm{mg} / \mathrm{L}$;

$f \quad$ is a unit conversion factor of 5.3943; and

$T \quad$ is time in days per year.

The estimated inputs from wastewater discharge were $221,000 \mathrm{lb} / \mathrm{yr}$ for nitrogen and 102,300 lb/yr for phosphorus for the Little River Basin. Wastewater discharges to the Little River ranged from 33 to 50 percent of the annual mean streamflow during 2003-04.

\section{Concentrations, and Estimated Loads and Yields of Nutrients}

Summary statistics for the concentrations of nutrients (ammonia nitrogen, nitrite-plus-nitrate nitrogen, total phosphorus, and orthophosphate) from March 2003 through November 2003 and from February 2004 through November 2004 at all sampling sites are shown in Appendix 1. These data provide the basis for analysis of concentrations, and estimated loads and yields at the selected sampling sites.

\section{Concentrations}

Although nutrients such as nitrogen and phosphorus are necessary for plant and animal life, in excessive quantities they can accelerate the growth of aquatic plants and cause algal blooms. Excessive aquatic growth may result in unsuitable habitat conditions for aquatic animals and can interfere with recreational activities such as fishing, swimming, and boating. Decomposition of aquatic-plant growth can cause odor and taste concerns in drinking water supplies and can consume dissolved oxygen, which can adversely affect aquatic life.

\section{Spatial Variability}

Concentrations of nitrate greater than $10 \mathrm{mg} / \mathrm{L}$ in drinking water can have adverse human-health effects. Concentrations of nitrite plus nitrate ranged from 0.36 to $5.7 \mathrm{mg} / \mathrm{L}$ at the nine sites (fig. 6 and Appendix 1). The highest concentration of nitrite plus nitrate, $5.7 \mathrm{mg} / \mathrm{L}$, was measured at the South Fork Little River site. The lowest concentration of nitrite plus nitrate, $0.36 \mathrm{mg} / \mathrm{L}$, was measured at the Casey Creek site. The median concentration of nitrite plus nitrate for all sites sampled was $3.6 \mathrm{mg} / \mathrm{L}$. The Sinking Fork near Cadiz site had the highest median nitrogen concentration of $4.6 \mathrm{mg} / \mathrm{L}$. Concentrations of ammonia nitrogen ranged from $<0.04$ to 0.66 $\mathrm{mg} / \mathrm{L}$ at the nine sites (Appendix 1). The highest concentration of ammonia nitrogen was observed at the South Fork Little River site.

Phosphorus is a common element in rocks; other sources of phosphorus include fertilizer, human and animal waste, and some detergents. Although no established aquatic-life criterion exists for total phosphorus, the USEPA recommends a maximum concentration of total phosphorus of $0.1 \mathrm{mg} / \mathrm{L}$ to discourage excessive growth of aquatic plants and algae. Concentrations of total phosphorus in 58 percent of the samples were greater than $0.1 \mathrm{mg} / \mathrm{L}$ (fig. 6). The median concentration of total phosphorus for all sites sampled was $0.13 \mathrm{mg} / \mathrm{L}$. Concentrations of orthophosphates ranged from $<0.006$ to $2.0 \mathrm{mg} / \mathrm{L}$. The highest concentration of orthophosphate was measured at the North Fork Little River site: $2.0 \mathrm{mg} / \mathrm{L}$. This sampling site is located immediately downstream from a wastewater-treatment facility. Sources of orthophosphate include weathering of soils, human and animal waste, some detergents, decaying plants, and fertilizer.

A Wilcoxson rank-sum nonparameteric statistical test (Helsel and Hirsch, 1992) was used to compare concentrations of nitrite plus nitrate, total phosphorus, and orthophosphate among the four fixed-network sites. A total of 23 samples were collected at each of the four fixed-network sites during 2003-04. 


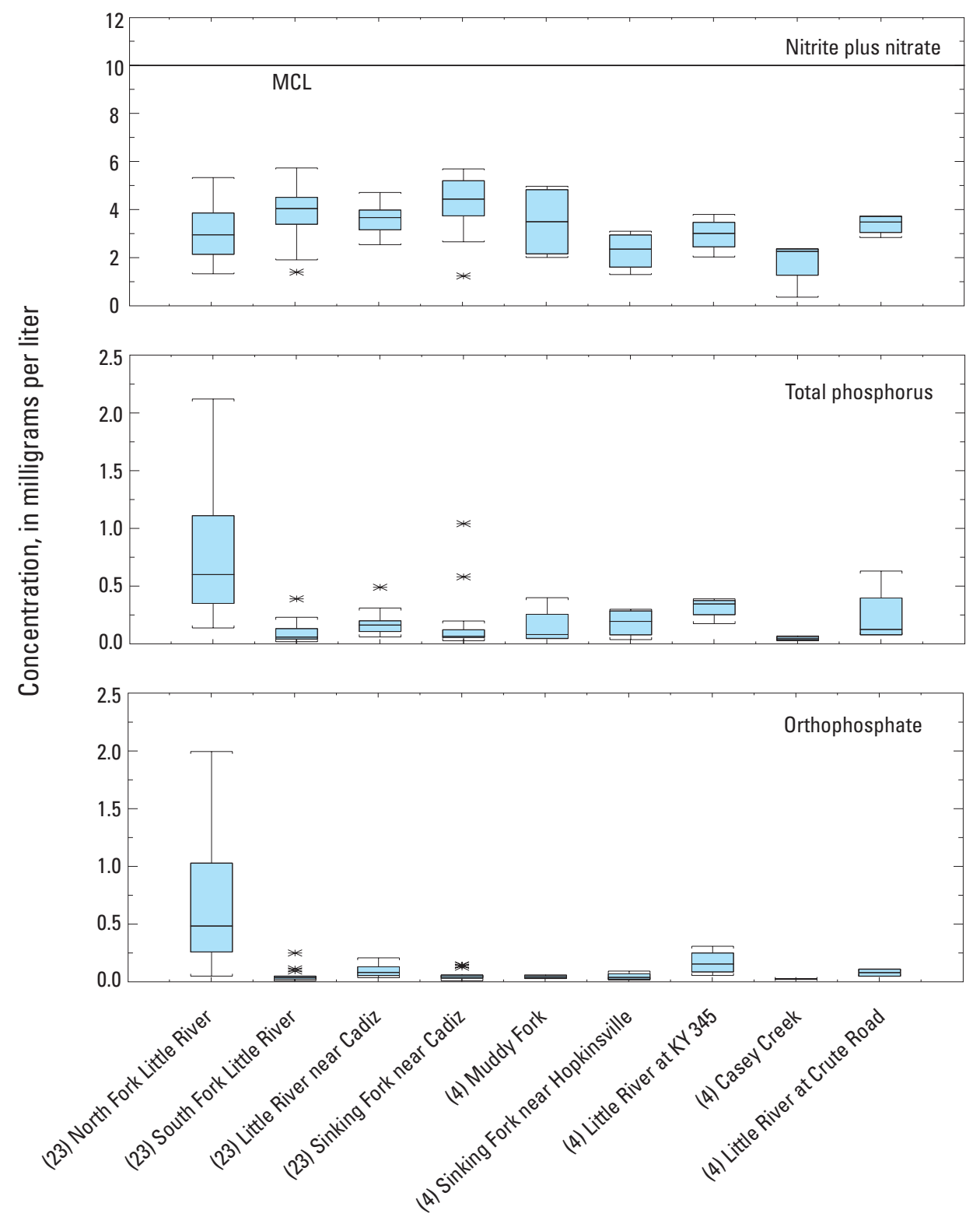

EXPLANATION

* Data outside

10th and 90th percentile

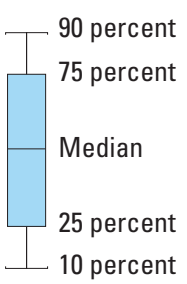

(4) Number of samples collected

MCL Maximum contaminant level

Figure 6. Concentrations of nitrite plus nitrate, total phosphorus, and orthophosphate at all sampling sites in the Little River Basin, Kentucky, 2003-04. 
The fixed-network sites sampled in the Little River Basin represent drainage areas in predominantly agricultural areas, forested areas, or a mixture of both. Urban areas represent only a small portion of the study area. Median concentrations of nitrite plus nitrate were lowest at the North Fork Little River site, which had the least agricultural and most urban land use (fig. 6). However, the North Fork Little River site had higher median concentrations of both total phosphorus and orthophosphate than samples from the other fixed-network sites, likely because of the urban sources in the North Fork Little River subbasin. The Sinking Fork near Cadiz site had a higher median concentration of nitrite plus nitrate than the other fixed-network sites, likely because this site had a higher percentage of drainage area in row crops. Median concentrations of total phosphorus and orthophosphate were lowest at the Sinking Creek near Cadiz site.

\section{Seasonal Variability}

Concentrations of nutrients vary seasonally. Concentrations of nitrite plus nitrate tended to be highest during spring and lowest in the fall in the Little River Basin. During late fall, plants become dormant and limit the uptake of available nutrients allowing for nutrients to build up in the soil. An increase in precipitation in the spring allows for the runoff of nutrients into the streams. In addition, nitrogen fertilizers are applied in the spring to row crops such as corn, adding more available nutrients to the soil that potentially can runoff into the streams. Precipitation decreases in the fall allowing plants to take up much of the available nutrients in the soil; thus, concentrations of nitrite plus nitrate decrease in streams. An insufficient number of samples were collected in the winter to perform a statistical analysis.

Differences in median concentrations of nitrite plus nitrate were minimal between fall and spring at the South Fork Little River site and the Sinking Fork near Cadiz site (fig. 7). The other fixed-network sites showed no difference between fall and spring. The South Fork Little River site also showed a difference between spring and summer ( $p$ value: 0.008 ). No difference was shown between fall and summer at any of the sites.

Seasonal variation in concentrations of total phosphorus was minimal, with the exception of the North Fork Little River site (fig. 8). The North Fork Little River site and the Little River near Cadiz site had high concentrations of orthophosphate in the fall and low concentrations of orthophosphate during spring (fig. 8). Concentrations of orthophosphate always were higher at the North Fork Little River site than at the other sites. A possible explanation is the effluent from the wastewater-treatment facilities on the North Fork Little River considerably contributes to streamflow. The percentage of total phosphorus that is orthophosphate varies seasonally. Concentrations of total phosphorus and orthophosphate are similar in the fall and summer at the fixed-network sites, but concentrations of orthophosphate are lower than concentrations of total phosphorus in the spring (fig.8). This probably is because orthophosphate is readily consumed by aquatic plants and algae during the spring growing season.

The Wilcoxson rank-sum test showed that median concentrations of total phosphorus and orthophosphate were different between fall and spring ( $p$ value: 0.024 and 0.014 , respectively) and between summer and spring ( $p$ value: 0.001 for both constituents) at the North Fork Little River site. Only median concentrations of orthophosphate at the Little River near Cadiz site were notable during the same seasons. Median concentrations of total phosphorus and orthophosphate were not similar among any of the three seasons at the South Fork Little River site and the Sinking Fork near Cadiz site.

\section{Estimated Loads and Yields}

Load represents the mass (usually pounds or tons) of a given waterborne constituent moving past a given point per unit of time. Annual loads can vary depending upon drainage basin size, hydrologic conditions, and land uses within a basin. Mean annual loads (in lb/yr) for nutrients were estimated using the LOADEST program at three of the four fixed-network sampling sites from samples collected March through November 2003 and February through November 2004 (table 7). The 95-percent confidence interval for each estimated annual load of ammonia nitrogen, nitrite plus nitrate, total phosphorus, and orthophosphate was calculated from the standard error of prediction provided by the LOADEST program. The confidence interval is shown in pounds per year. Loads were not estimated at the Sinking Fork near Cadiz site, because a streamflow relation between this site and the Little River near Cadiz site could not be established; however, estimates for this site are available (Michael C. Ierardi (U.S. Geological Survey, unpub. data., 2006) (table 7).

The coefficients of determination $\left(\mathrm{R}^{2}\right)$ for the bestfit regression models for loads of nitrite plus nitrate, total phosphorus, orthophosphate, and suspended sediment are listed in table 8 . High $\mathrm{R}^{2}$ values indicate that the models for all four constituents successfully simulated the variability in constituent loads at the three fixed-network sites. Overall, the model simulations for nitrite plus nitrate showed the highest $\mathrm{R}^{2}$ values. Based on $\mathrm{R}^{2}$ values, the model simulations for total phosphorus showed a better fit than the orthophosphate model. The better fit for total phosphorus likely is related to the suspended components of total phosphorus. Generally, suspended material has a stronger relation to streamflow than do dissolved components such as orthophosphate. Model simulations for suspended sediment showed high $\mathrm{R}^{2}$ values for all three fixed-network sites.

The largest estimated mean annual load of nitrite plus nitrate among the three fixed-network sites was at the Little River near Cadiz site (2,500,000 lb/yr) (table 7). This site also had the largest estimated mean annual load of total phosphorus $(166,000 \mathrm{lb} / \mathrm{yr})$. The estimated mean annual load of orthophosphate was $65,000 \mathrm{lb} / \mathrm{yr}$, which is about 40 percent of the mean annual load of total phosphorus at this site. 

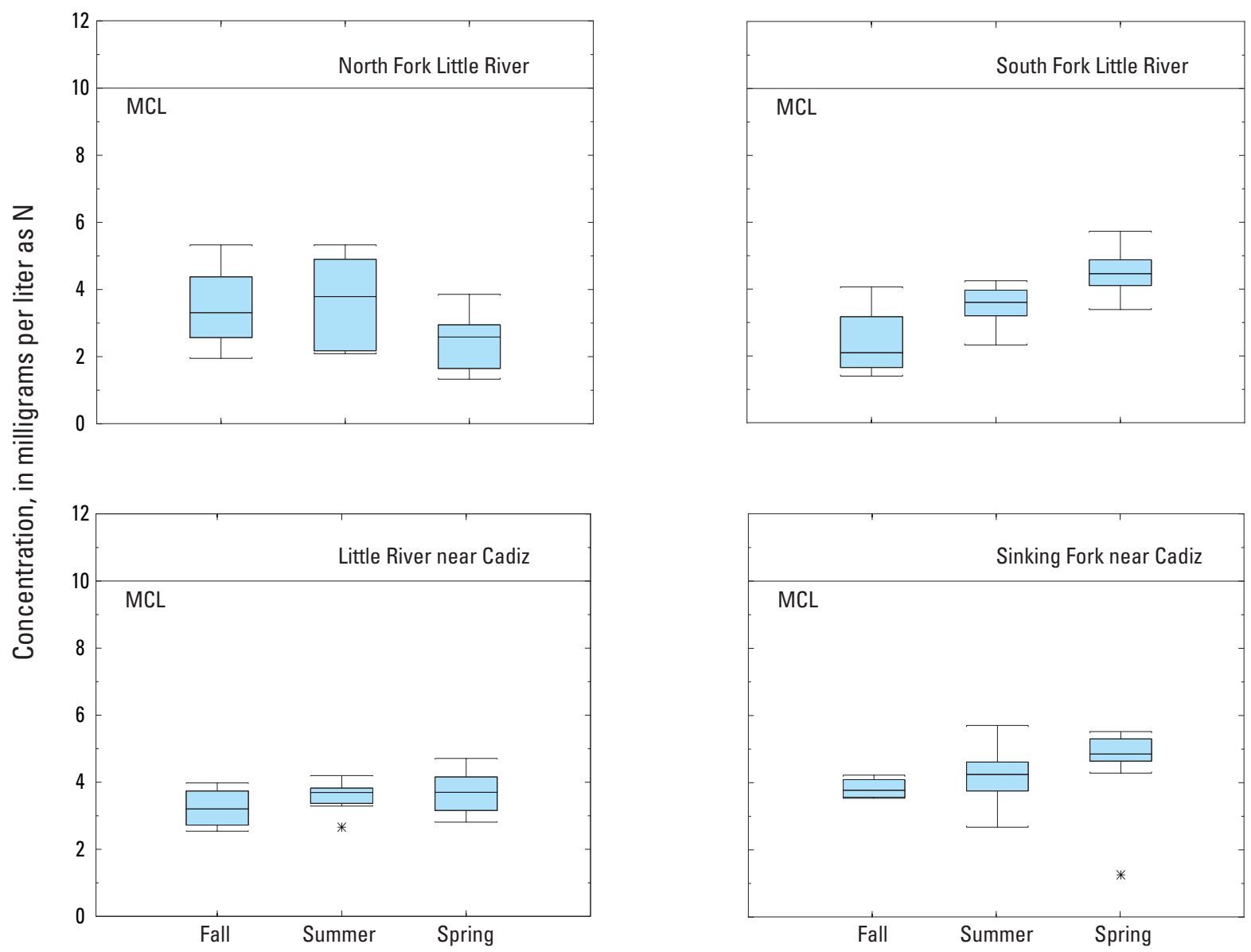

EXPLANATION

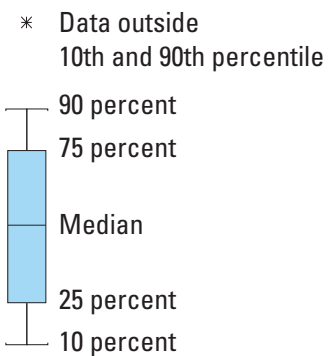

MCL Maximum contaminant level

Figure 7. Seasonal distribution of concentrations of nitrite plus nitrate for four fixed-network sites in the Little River Basin, Kentucky, 2003-04. 


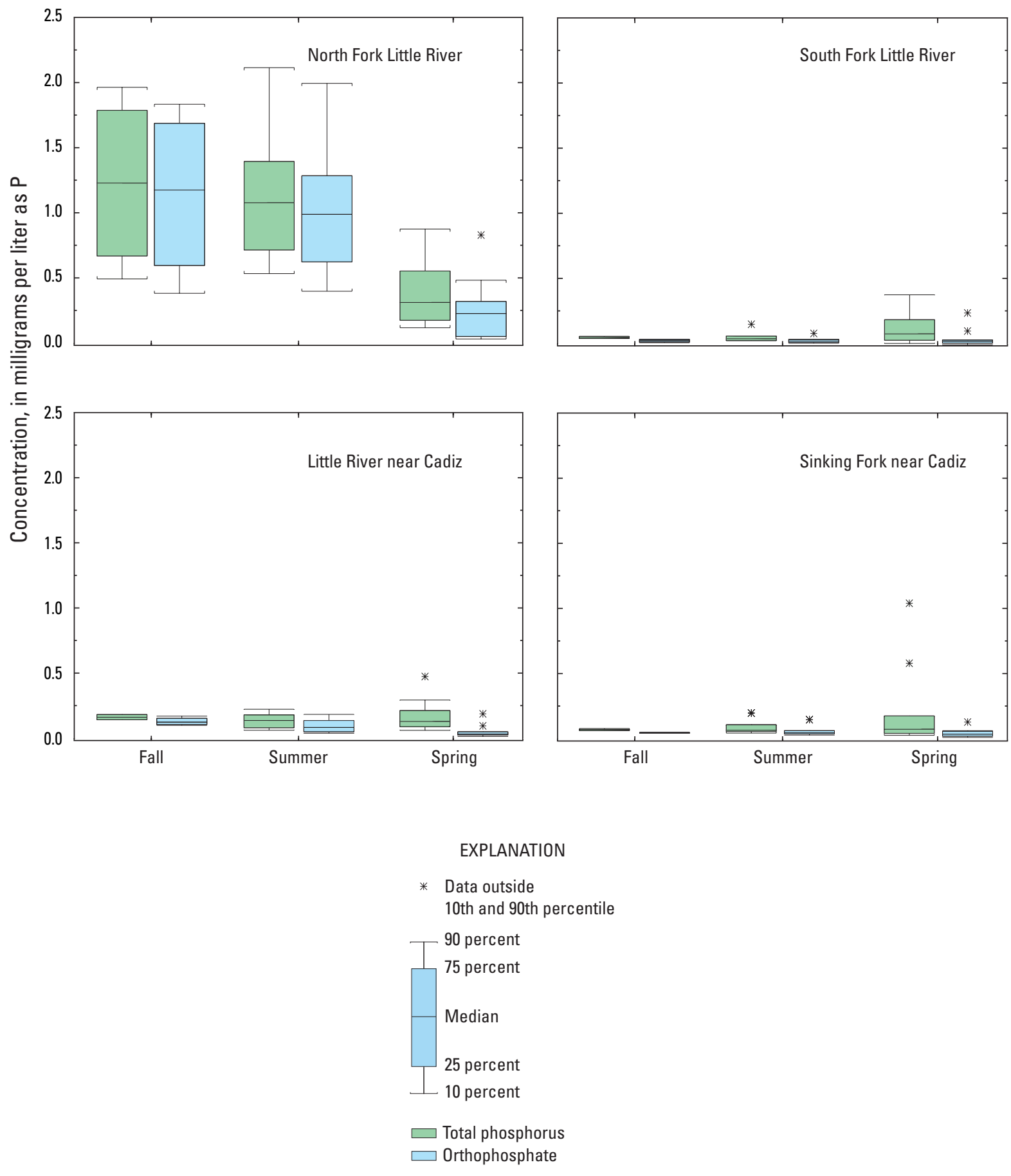

Figure 8. Seasonal distribution of concentrations of total phosphorus and orthophosphate for four fixed-network sites in the Little River Basin, Kentucky, 2003-04. 
Table 7. Estimated mean annual load and yield of nutrients and suspended sediment at the fixed-network sites in the Little River Basin, Kentucky, 2003-04.

[lb/yr, pound per year; $1 \mathrm{~b} / \mathrm{yr} / \mathrm{mi}^{2}$, pounds per year per square mile; DA, drainage area; $\mathrm{mi}^{2}$, square miles; ---, not available]

\begin{tabular}{|c|c|c|c|c|c|}
\hline \multirow[b]{2}{*}{ Constituent } & \multirow{2}{*}{$\begin{array}{c}\text { Mean } \\
\text { annual load } \\
\text { (lb/yr) }\end{array}$} & \multicolumn{2}{|c|}{$\begin{array}{c}\text { 95-percent confidence } \\
\text { interval }\end{array}$} & \multirow{2}{*}{$\begin{array}{l}\text { Standard } \\
\text { error of } \\
\text { prediction }\end{array}$} & \multirow{2}{*}{$\begin{array}{c}\text { Mean annual } \\
\text { yield } \\
\left(\mathrm{lb} / \mathrm{yr} / \mathrm{mi}^{2}\right)\end{array}$} \\
\hline & & Lower & Upper & & \\
\hline \multicolumn{6}{|c|}{$\begin{array}{l}\text { North Fork Little River near Hopkinsville, Ky. } \\
\qquad\left(\mathrm{DA}=58 \mathrm{mi}^{2} \text { ) }\right.\end{array}$} \\
\hline $\begin{array}{c}\text { Ammonia (as N) } \\
\text { dissolved }\end{array}$ & 13,000 & 7,800 & 20,000 & 3,000 & 190 \\
\hline (as N), dissolved & 450,000 & 396,000 & 516,000 & 31,000 & 6,700 \\
\hline $\begin{array}{l}\text { Phosphorus (as P), total } \\
\text { Orthophosphate (as P) }\end{array}$ & 107,000 & 87,000 & 129,000 & 10,000 & 1,600 \\
\hline dissolved & 74,000 & 60,000 & 90,000 & 7,500 & 1,100 \\
\hline Suspended sediment & $30,000,000$ & $7,000,000$ & $23,000,000$ & $4,400,000$ & 450,000 \\
\hline \multicolumn{6}{|c|}{$\begin{array}{l}\text { South Fork Little River near Hopkinsville, Ky. } \\
\qquad\left(\mathrm{DA}=67 \mathrm{mi}^{2}\right)\end{array}$} \\
\hline $\begin{array}{l}\text { Ammonia (as N), } \\
\text { dissolved }\end{array}$ & --- & --- & --- & --- & --- \\
\hline (as N), dissolved & 780,000 & 678,000 & 890,000 & 54,000 & 13,000 \\
\hline $\begin{array}{l}\text { Phosphorus (as P), total } \\
\text { Orthophosphate (as P) }\end{array}$ & 32,000 & 14,500 & 62,000 & 12,000 & 550 \\
\hline dissolved & 14,000 & 6,100 & 29,000 & 5,900 & 240 \\
\hline Suspended sediment & $18,000,000$ & $3,500,000$ & $55,000,000$ & $14,000,000$ & 310,000 \\
\hline \multicolumn{6}{|c|}{$\begin{array}{l}\text { Little River near Cadiz, Ky. } \\
\qquad\left(D A=244 \mathrm{mi}^{2}\right)\end{array}$} \\
\hline $\begin{array}{l}\text { Ammonia (as N), } \\
\text { dissolved } \\
\text { Nitrite plus nitrate }\end{array}$ & --- & --- & --- & --- & --- \\
\hline (as N), dissolved & $2,500,000$ & 230,000 & $2,800,000$ & 103,000 & 10,000 \\
\hline $\begin{array}{l}\text { Phosphorus (as P), total } \\
\text { Orthophosphate (as P) }\end{array}$ & 166,000 & 102,000 & 250,000 & 39,000 & 660 \\
\hline dissolved & 65,000 & 46,000 & 89,000 & 11,000 & 270 \\
\hline Suspended sediment & $84,000,000$ & 59,000 & 620,000 & 150,000 & 340,000 \\
\hline \multicolumn{6}{|c|}{$\begin{array}{l}\text { Sinking Fork near Cadiz, Ky. } \\
\qquad\left(D A=107 \mathrm{mi}^{2}\right)\end{array}$} \\
\hline Total nitrogen & $1,200,000$ & -- & -- & 660,000 & 12,000 \\
\hline Phosphorus (as P), total & 114,000 & -- & -- & 67,000 & 1,000 \\
\hline
\end{tabular}

${ }^{1}$ Data from Michael C. Ierardi, U.S. Geological Survey, unpub. data, 2006. 


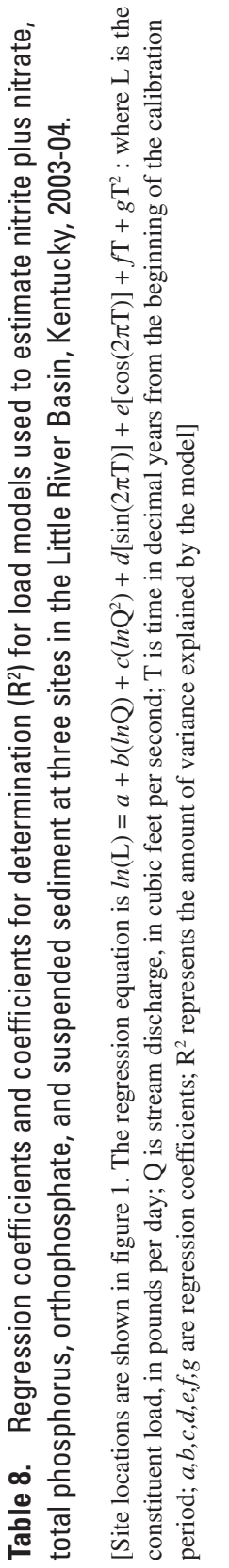

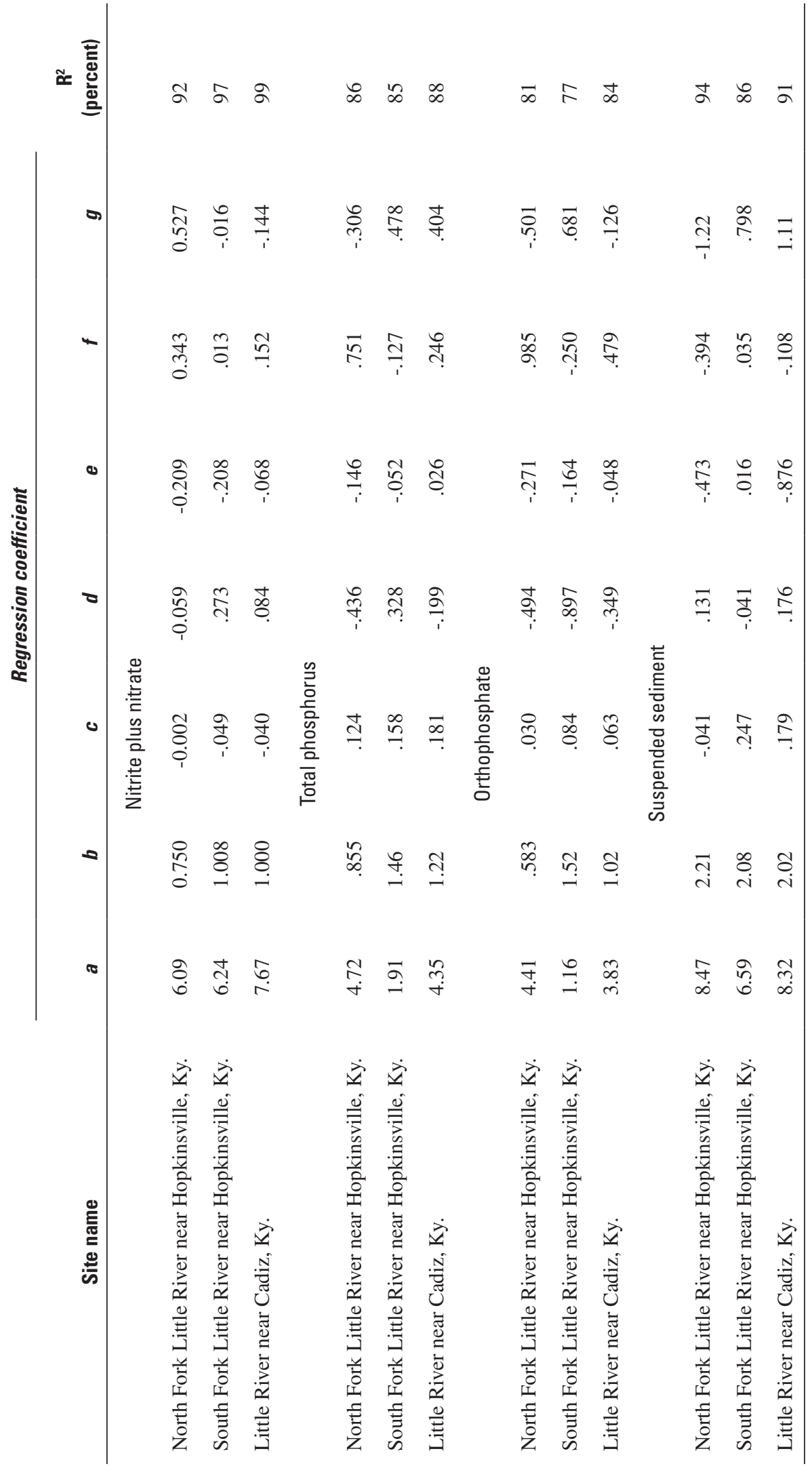


Estimates of mean annual total load of nitrite plus nitrate and total phosphorus during 1985-97 reported by Crain (2001) and estimates reported by Michael C. Ierardi (U.S. Geological Survey, unpub. data, 2006) are similar to the estimates in this report. The estimated mean annual load of nitrite plus nitrate and total phosphorus reported during 1985-97 was 2,100,000 and 212,000 lb/yr, respectively (Crain, 2001). Estimated mean annual loads for total nitrogen were 2,000,000 lb/yr and for total phosphorus were 210,000 lb/yr (Michael C. Ierardi, U.S. Geological Survey, unpub. data, 2006). Although Michael C. Ierardi (U.S. Geological Survey, unpub. data, 2006) reported mean annual loads for total nitrogen and not nitrite plus nitrate, the major form of nitrogen in the Little River Basin is nitrite plus nitrate (about 87 percent of total nitrogen) (Crain, 2001). Load estimates with long periods of record are more reliable than estimates from sites with short periods of record.

Of the two main tributaries upstream from the Little River near Cadiz site, the North Fork Little River site contributed the greatest amount of total phosphorus to the study area with an estimated mean annual load of $107,000 \mathrm{lb} / \mathrm{yr}$ or about 64 percent of the total mean annual load at the Little River near Cadiz site, from about 27 percent of the overall drainage area. The South Fork Little River site contributed an estimated mean annual load of total phosphorus of 32,000 lb/yr, which was about 20 percent of the total mean annual load at the Little River near Cadiz site, from 24 percent of the overall drainage area.

The estimated mean annual loads for orthophosphate for the North Fork Little River site and South Fork Little River site were 74,000 and 14,000 lb/yr, respectively. The mean annual load of orthophosphate represented a larger percentage of the mean annual load of total phosphorus at the North Fork Little River site (68 percent) than at the South Fork Little River site (44 percent). A possible reason for the larger percentage of orthophosphate to total phosphorus at the North Fork Little River site is a wastewater-treatment facility, which discharges just upstream from the sampling site. The estimated mean annual load of nitrite plus nitrate for the South Fork Little River site was 780,000 lb/yr. The North Fork Little River site had an estimated mean annual load of nitrite plus nitrate of 450,000 lb/yr.

Yields are defined as the amount of load per unit area and are useful for comparing basins with varying size, land use, and physiography. Yields for ammonia nitrogen, nitrite plus nitrate, total phosphorus, and orthophosphate were computed for each of the three fixed-network sites (table 7).

Estimated historical mean annual yields (Crain, 2001; Michael C. Ierardi, U.S. Geological Survey, unpub. data, 2006) of nitrite plus nitrate and total phosphorus for the Little River near Cadiz site were similar to those computed from samples collected during 2003-04. The estimated mean annual yields of nitrite plus nitrate and total phosphorus reported by Crain (2001) were 8,600 and $870(\mathrm{lb} / \mathrm{yr}) / \mathrm{mi}^{2}$, respectively. Estimated mean annual yields of total nitrogen and total phosphorus from Michael C. Ierardi (U.S. Geological Survey, unpub. data,
2006) were 8,200 and 860 (lb/yr)/mi² , respectively; whereas, the estimated mean annual yield of nitrite plus nitrate was $10,000(\mathrm{lb} / \mathrm{yr}) / \mathrm{mi}^{2}$ and the estimated mean annual yield for total phosphorus was $660(\mathrm{lb} / \mathrm{yr}) / \mathrm{mi}^{2}$ for $2003-04$ at the Little River near Cadiz site. Mean annual streamflow for the Little River near Cadiz site was $389 \mathrm{ft}^{3} / \mathrm{s}$ for water years 2003-04, compared to $372 \mathrm{ft}^{3} / \mathrm{s}$ for water years $1985-97$, and $355 \mathrm{ft}^{3} / \mathrm{s}$ for the period reported by Michael C. Ierardi (U.S. Geological Survey, unpub. data, 2006).

The North Fork Little River site had the largest estimated mean annual yield of total phosphorus $\left(1,600(\mathrm{lb} / \mathrm{yr}) / \mathrm{mi}^{2}\right)$ and orthophosphate $\left(1,100(\mathrm{lb} / \mathrm{yr}) / \mathrm{mi}^{2}\right)$. Thirteen percent of the land is considered urban in this subbasin. A principal source of phosphorus for the North Fork Little River is discharge from wastewater-treatment facilities. The mean annual yields for total phosphorus and orthophosphate for the Little River near Cadiz site and the South Fork Little River site were much lower, with the Little River near Cadiz site having slightly larger yields of the two (table 7). The South Fork Little River site had the largest estimated mean annual yield of nitrite plus nitrate $\left(13,000(\mathrm{lb} / \mathrm{yr}) / \mathrm{mi}^{2}\right)$, followed by the Little River near Cadiz site $\left(10,000(\mathrm{lb} / \mathrm{yr}) / \mathrm{mi}^{2}\right)$, and the North Fork Little River site $\left(6,700(\mathrm{lb} / \mathrm{yr}) / \mathrm{mi}^{2}\right)$. Estimated mean annual yields for nitrogen and phosphorus from Crain (2001) and Michael C. Ierardi (U.S. Geological Survey, unpub. data, 2006) were similar to the mean annual yields estimated in this report.

\section{Concentrations, and Estimated Loads and Yields of Suspended Sediment}

Summary statistics for the concentrations of suspended sediment from March 2003 through November 2003 and from February 2004 through November 2004 at all sampling sites are shown in Appendix 1. These data provide the basis for analysis of concentrations, and estimated loads and yields at the selected sampling sites.

\section{Concentrations}

Suspended sediment is all particulate matter suspended in the water column resulting from streambed resuspension, rock weathering, and soil erosion. Concentrations of suspended sediment are affected by natural conditions (streambank erosion, steep slopes, and forest fires) and anthropogenic activities (construction, timber harvesting, and certain agricultural practices).

High concentrations of suspended sediment can cause habitat destruction and limit light penetration throughout the water column. In addition, suspended sediment has a major role in the transport and fate of contaminants. Contaminants may sorb onto the surface of the suspended sediments and be transported and deposited in other areas downstream. 


\section{Spatial Variability}

Concentrations of suspended sediment generally were low in the Little River Basin (fig. 9). The median concentration of suspended sediment for all sites sampled was $12 \mathrm{mg} / \mathrm{L}$. The highest concentration of suspended sediment was measured at the Sinking Fork near Cadiz site $(1,020 \mathrm{mg} / \mathrm{L})$ during a spring runoff event.

Concentrations of suspended sediment for the four fixednetwork sites were grouped by site and compared by means of the Wilcoxson rank-sum test. Differences in median concentrations of suspended sediment were not significant ( $p$ value: $>0.05$ ) among any of the fixed-network sites.

\section{Seasonal Variability}

Concentrations of suspended sediment were higher during spring and low during the fall (fig. 10). Concentrations of suspended sediment were grouped by season and compared by means of the Wilcoxson rank-sum test. Differences in median concentrations of suspended sediment were not significant ( $p$ value: $>0.05$ ) at the South Fork Little River site among any season, while samples from the Little River near Cadiz site had differences in median concentrations of suspended sediment that were significant among all seasons. Differences in median concentrations of suspended sediment at the North Fork Little River site were significant between summer and fall ( $p$ value: 0.04 ) and between spring and fall ( $p$ value:

0.006). The Sinking Fork near Cadiz site and the Little River near Cadiz site had differences in median concentrations of suspended sediment that were significant between spring and summer ( $p$ value: 0.01 and 0.03 , respectively).

\section{Estimated Loads and Yields}

Mean annual loads (in lb/yr) for suspended sediment were estimated using the LOADEST program at three of the four fixed-network sites from samples collected during 2003-04 (table 7). The 95-percent confidence interval for each estimated annual load of suspended sediment has been calculated from the standard error of prediction provided by the LOADEST program; the confidence interval is shown in pounds per year. Loads of suspended sediment were not estimated at the Sinking Fork near Cadiz site, because a streamflow relation between this site and the Little River near Cadiz site could not be established. Annual loads vary depending upon drainage basin size, hydrologic conditions, and land uses within a basin.

Estimated loads of suspended sediment were largest at the Little River near Cadiz site, where the mean annual load for 2003-04 was about 84,000,000 lb/yr (table 7). The largest estimated mean annual yield was $450,000(\mathrm{lb} / \mathrm{yr}) / \mathrm{mi}^{2}$ at the North Fork Little River site. The smallest mean annual loads and yields of suspended sediment, 18,000,000 lb/yr and $310,000(\mathrm{lb} / \mathrm{yr}) / \mathrm{mi}^{2}$, respectively, were estimated at the South Fork Little River site. 


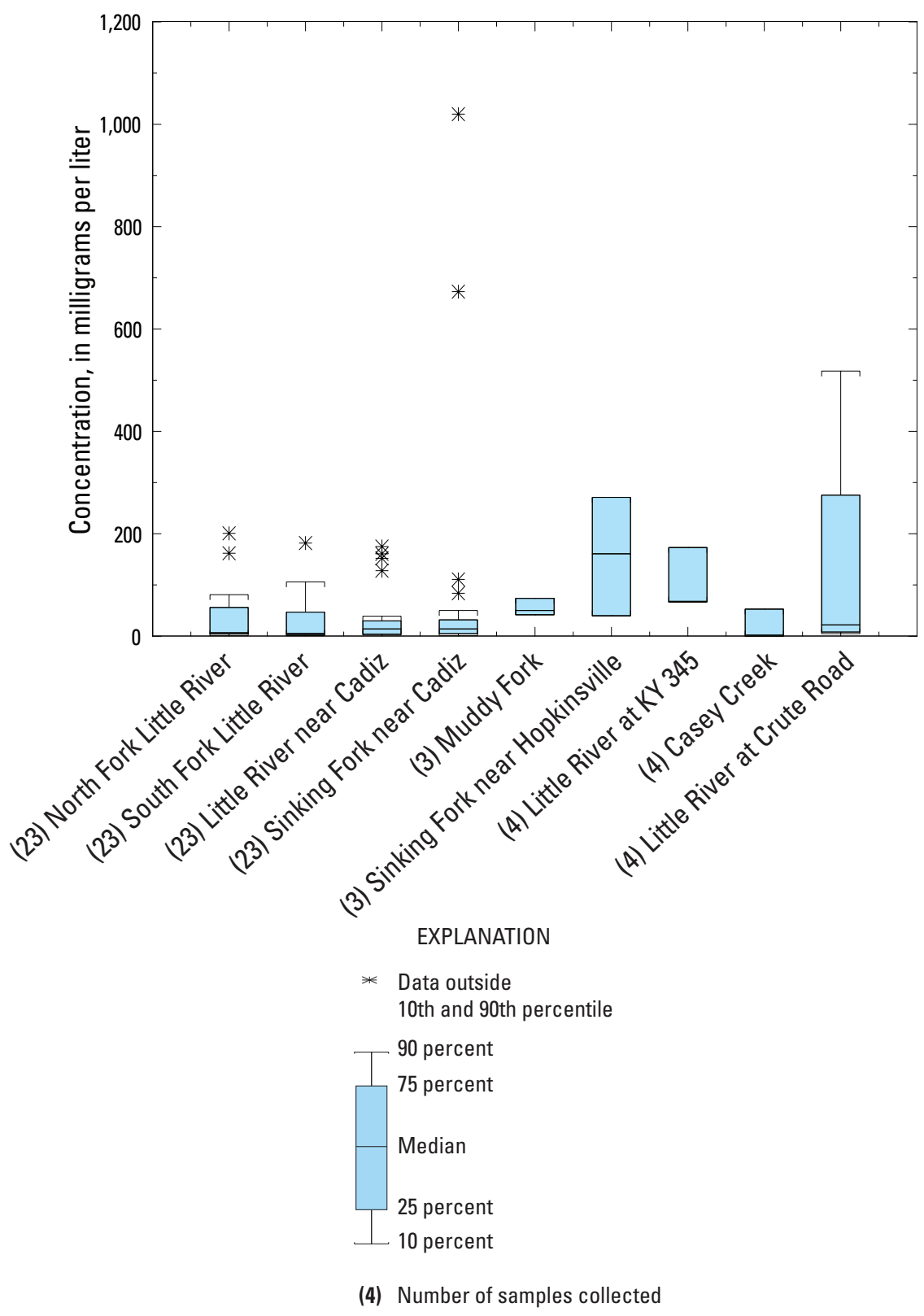

Figure 9. Concentrations of suspended sediment at all sampling sites in the Little River Basin, Kentucky, 2003-04. 

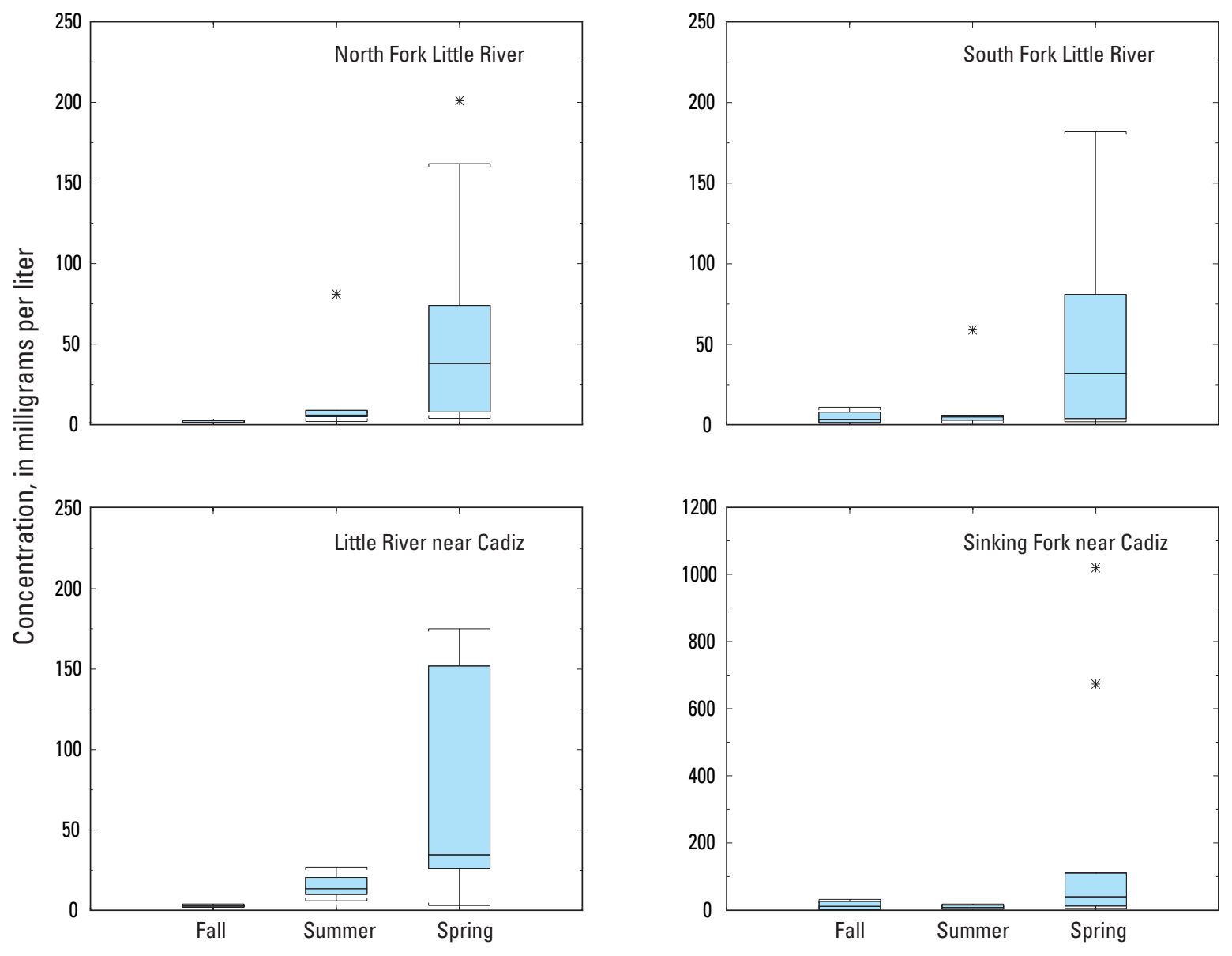

EXPLANATION

* Data outside 10th and 90th percentile

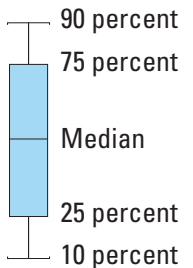

Figure 10. Seasonal distribution of concentrations of suspended sediment for four fixed-network sites in the Little River Basin, Kentucky, 2003-04. 


\section{Conclusions}

Concentrations and estimated loads and yields of nitrite plus nitrate, total phosphorus, orthophosphate, and suspended sediment were evaluated in streams of the Little River Basin of western Kentucky. Water samples were collected in streams in the Little River Basin during 2003-04 as part of study in cooperation with the Kentucky Department of Agriculture. A total of 92 water samples were collected at four fixed-network sites from March through November 2003 and from February through November 2004. An additional 20 samples were collected at five synoptic-network sites during the same period. The Little River Basin encompasses about 600 square miles in Christian and Trigg Counties, and a portion of Caldwell County.

Median concentrations of nitrogen, phosphorus, and suspended sediment varied spatially and seasonally. Concentrations of nitrogen were higher in the spring (March-May) after fertilizer application and runoff. The highest concentration of nitrite plus nitrate, 5.7 milligrams per liter (mg/L), was detected at the South Fork Little River site. The Sinking Fork near Cadiz site had the highest median concentration of nitrite plus nitrate $(4.6 \mathrm{mg} / \mathrm{L})$. Median concentrations of nitrite plus nitrate were notable between spring and fall (SeptemberNovember) at the South Fork Little River site and the Sinking Fork near Cadiz site. The median concentrations at the other fixed-network sites showed no differences between the seasons.

The North Fork Little River site and the Little River near Cadiz site had higher concentrations of orthophosphate in the fall and lower concentrations in the spring. Concentrations of orthophosphate remained high during the summer (JuneAugust) at the North Fork Little River site probably because of the contribution of wastewater effluent to streamflow. Fiftyeight percent of the concentrations of total phosphorus at the nine sites exceeded the U.S. Environmental Protection Agency recommended maximum concentration limit of $0.1 \mathrm{mg} / \mathrm{L}$.

Concentrations of suspended sediment were high in the spring during runoff and low in the fall. The highest concentration of suspended sediment $(1,020 \mathrm{mg} / \mathrm{L})$ was observed at the Sinking Fork near Cadiz site. The median concentration of suspended sediment for all sites sampled was $12 \mathrm{mg} / \mathrm{L}$. A nonparameteric statistical test (Wilcoxson rank-sum) showed that the median concentrations of suspended sediment were not different among any of the fixed-network sites.

Commercial-fertilizer and livestock-waste application on corn and soybean fields is the principal source of nutrients for most of the Little River Basin. Some of these nutrients from agricultural nonpoint sources eventually are transported to streams by surface runoff, erosion of sediment, or ground-water discharge. Sources of nutrients in the urban areas (Hopkinsville) mainly are from effluent discharge from wastewater-treatment facilities and fertilizer applications to lawns and golf courses. The Little River near Cadiz site contributed larger estimated mean annual loads of nitrite plus nitrate $(2,500,000$ pounds per year $(\mathrm{lb} / \mathrm{yr}))$ and total phosphorus $(160,000 \mathrm{lb} / \mathrm{yr})$ than the other three fixed-network sites. Of the two main tributaries upstream from the Little River near Cadiz site, the North Fork Little River was the greatest contributor of total phosphorus to the study area with an estimated mean annual load of $107,000 \mathrm{lb} / \mathrm{yr}$ or about 64 percent of the total mean annual load at the Little River near Cadiz site. The other main upstream tributary, South Fork Little River, had an estimated mean annual load of total phosphorus that was about 20 percent of the mean annual load at the Little River near Cadiz site. Estimated loads of suspended sediment were largest at the Little River near Cadiz site, where the mean annual load for 2003-04 was about 84,000,000 lb/yr. The North Fork Little River contributed an estimated 36 percent of the mean annual load of suspended sediment at the Little River near Cadiz site; the South Fork Little River contributed an estimate of 18 percent of the mean annual load at this site.

The North Fork Little River site had the largest estimated mean annual yield of total phosphorus (1,600 pounds per year per square mile $\left.(\mathrm{lb} / \mathrm{yr}) / \mathrm{mi}^{2}\right)$ and orthophosphate $\left(1,100(\mathrm{lb} / \mathrm{yr}) / \mathrm{mi}^{2}\right)$. A principal source of phosphorus for the North Fork Little River is discharge from wastewater-treatment facilities. The largest estimated mean annual yield of nitrite plus nitrate was at the South Fork Little River site. The North Fork Little River site had the largest estimated mean annual yield of suspended sediment $\left(450,000(\mathrm{lb} / \mathrm{yr}) / \mathrm{mi}^{2}\right)$. The smallest estimated mean annual loads and yields of suspended sediment were at the South Fork Little River site.

\section{Acknowledgments}

The author is grateful for the technical reviews by Terence Messinger (USGS West Virginia Water Science Center) and Brenda Smith (USGS Missouri Water Science Center). The agricultural crop sales data provided by Ernest Collins (Kentucky Department of Agriculture) is appreciated. Donnie Keeling, R. Steven Darnell, and James Filbeck (USGS Kentucky Water Science Center, Paducah field office, Paducah, Ky.) and Greg McCombs and Zeke Hensley (USGS Kentucky Water Science Center, Louisville, Ky.) are thanked for their assistance in collecting samples for this study. Joseph Vrabel (USGS Texas Water Science Center) is thanked for providing assistance on computing the loads. Aimee Downs (USGS Kentucky Water Science Center, Louisville, Ky.) is thanked for assistance with GIS illustrations and summarizing the agricultural crop sales data. Bonnie Stich Fink (USGS Publishing Network, PSC 8, Louisville, Ky.) is thanked for editing and preparing the report for publication. 


\section{References Cited}

Akaike, H., 1981, Likelihood of a model and information criterion: Journal of Econometrics, v. 16, p. 3-14.

Craig, N., and Kuenzler, E.J., 1983, Land use, nutrient yield, and eutrophication in the Chower River Basin: Raleigh, N.C., The University of North Carolina Research Institute, Report No. 205.

Crain, A.S., 2001, Estimated loads and yields of suspended solids and water-quality constituents in Kentucky streams: U.S. Geological Survey Water-Resources Investigations Report 01-4075, 125 p.

Crain, A.S., 2006, Occurrence, distribution, loads, and yields of selected pesticides in the Little River Basin, Kentucky, 2003-04: U.S. Geological Survey Scientific Investigations Report 2006-5142, 25 p.

Edwards, T.K., and Glysson, G.D., 1998, Field methods for measurement of fluvial sediment: U.S. Geological Survey Techniques of Water-Resources Investigations, book 3, chap. C2., 80 p.

Fishman, M.J., ed., 1993, Methods of analysis by the U.S. Geological Survey National Water Quality Laboratory-Determination of inorganic and organic constituents in water and fluvial sediments: U.S. Geological Survey Open-File Report 93-125, 217 p.

Fishman, M.J., and Friedman, L.C., 1989, Methods for determination of inorganic substances in water and fluvial sediments: U.S. Geological Survey Techniques of WaterResources Investigations, book 5, chap. A1, 545 p.

Goolsby, D.A., Battaglin, W.A., Lawrence, G.B., Artz, R.S., Aulenbach. B.T., Hooper, R.P., Keeney, D.R., and Stensland, G.J., 1999, Flux and sources of nutrients in the Mississippi-Atchafalaya River Basin-Topic 3 report for the integrated assessment on the hypoxia in the Gulf of Mexico: Silver Springs, Md., NOAA Coastal Ocean Program Decision Analysis Series no. 17, 130 p.

Helsel, D.R., and Hirsch, R.M., 1992, Statistical methods in water resources: New York, Elsevier Science Publishers, $522 \mathrm{p}$.

Hoos, A.B., Robinson, J.A., Aycock, R.A., Knight, R.R., and Woodside, M.D., 1999, Sources, instream transport, and trends of nitrogen, phosphorus, and sediment in the Lower Tennessee River Basin, 1980-96: U.S. Geological Survey Water-Resources Investigations Report 99-4139, 96 p.

Insightful Corporation, 2005, S-Plus for Windows-Professional Developer, version 7: Seattle, Wash.

Kentucky Agricultural Statistics Service, 2004, Kentucky agriculture statistics, 2003-2004: Louisville, Ky., 156 p.
Kentucky Environmental and Public Protection Cabinet-Division of Water, 2002, 2002 305(b) report to Congress on water quality for Kentucky: accessed August 15, 2005, at URL http://www.water.ky.gov/NR/rdonyles/C5DD8D0E3854-4FSE-9E42-CFAC455E09C4/0/2002-305b.pdf

Kentucky Environmental and Public Protection Cabinet-Division of Water, 2003, 2002 303(d) list of waters for Kentucky: accessed August 15, 2005, at URL http://www. water.ky.gov/NR/rdonyles/F91E50FC-3F98-410C-92C37823C2E886BB/0/303d_2002.pdf

Kentucky Environmental and Public Protection Cabinet-Division of Water, 2005, 2004 303(d) list of waters for Kentucky: accessed August 15, 2005, at URL http://www. water.ky.gov/NR/rdonlyres/E7D19E45-3775-42D5-A1C9680F59B67993/0/2004_draft_303d.pdf

Kentucky Environmental and Public Protection Cabinet-Division of Water, 2006, AFOs and CAFOs: accessed July 20, 2006, at URL http://www.water.ky.gov/permitting/ wastewaterpermitting/KPDES/cafo

McDowell, R.C., 1986, The geology of Kentucky-A text to accompany the geologic map of Kentucky: U.S. Geological Survey Professional Paper 1151-H, 76 p.

McDowell, R.C., Grabowski, G.J. Jr., and Moore, S.L., 1981, Geologic Map of Kentucky: U.S. Geological Survey, scale 1:250,000, 4 sheets.

McMahon, G., and Lloyd, O.B., Jr., 1995, Water-quality assessment of the Albermarle-Pamlico Drainage Basin, North Carolina and Virginia-Environmental setting and water-quality issues: U.S. Geological Survey Open-File Report 95-136, 72 p.

Mueller, D.K., Martin, J.D., and Lopes, T.J., 1997, Qualitycontrol design for surface-water sampling in the National Water-Quality Assessment Program: U.S. Geological Survey Open-File Report 97-223, 17 p.

National Atmospheric Deposition Program, 2006, NADP/NTN Site List: accessed May 22, 2006, at URL http://nadp.sws. uiuc.edu/nadpdatal

National Oceanic and Atmospheric Administration, 2003, Climatological data annual summary, Kentucky, v. 98, no. 13: accessed November 10, 2005, at URL http://wwwl. ncdc.noaa.gov/pub/orders/2847426F-9724-4EC5-375F048E78784E08.PDF

National Oceanic and Atmospheric Administration, 2004, Climatological data annual summary, Kentucky, v. 99, no. 13: accessed November 10, 2005, at URL http://wwwl. ncdc.noaa.gov/pub/orders/B8588E7D-C131-5FE4-8776EB62FCB95C3E.PDF 
Patton, C.J., and Kryskalla, J.R., 2003, Methods of analysis by the U.S. Geological Survey National Water Quality Laboratory-Evaluation of alkaline persulfate digestion as an alternative to Kjeldahl digestion for determination of total and dissolved nitrogen and phosphorus in water: U.S. Geological Survey Water-Resources Investigations Report 03-4174, 33 p.

Patton, C.J., and Truitt, E.P., 1992, Methods of analysis by the U.S. Geological Survey National Water Quality Laboratory-Determination of the total phosphorus by the Kjeldahl Digestion Method and an Automated Colorimetric Finish That Includes Dialysis: U.S. Geological Survey Open-File Report 92-146, 39 p.

Rantz, S.E., and others, 1982, Measurement and computation of streamflow-vol. 2-Computation and discharge: U.S. Geological Survey Water-Supply Paper 2175, 2 v., $631 \mathrm{p}$.

Ray, J.A., Webb, J.S., and O'Dell, P.W., 1994, Groundwater Sensitivity Regions of Kentucky: accessed April 7, 2006, at URL http://kgsweb.uky.edu/download/wrs/sensitivity.pdf

Ruddy, B.C, Lorenz, D.L., and Mueller, D.K., 2006, Countylevel estimates of nutrient inputs to the land surface of the conterminous United States, 1982-2001: U.S. Geological Survey Scientific-Investigations Report 2006-5012, 17 p.

Runkel, R.L., Crawford, C.G., and Cohn, T.A., 2004, Load estimator (LOADEST)-A FORTRAN program for estimating constituent loads in streams and rivers: U.S. Geological Survey Techniques and Methods Report 4-A5, 75 p.

University of Kentucky, 2001, Nutrient management in Kentucky: accessed April 4, 2006, at URL http://www.ca.uky. edu.agc/pubs/ip/ip71/IP71.pdf

U.S. Census Bureau, 2002, Census 2000 data for the State of Kentucky: accessed August 15, 2005, at URL http://www. census.gov/census2000/states/ky.html
U.S. Department of Agriculture, 2004, 2002 Census of Agriculture-United States-Summary of State Data, Volume 1: Geographic Area Series Part 51, National Agriculture Statistics Service: accessed May 22, 2006, at URL http://www. nass.usda.gov/census/census02/volume1/us/index1.htm

U.S. Environmental Protection Agency, 1993, Determination of phosphorus by semi-automated colorimetry, Rev. 2.0, Methods for the determination of inorganic substances in environmental samples: U.S. Environmental Protection Agency EPA report number 600/R-93-100.

U.S. Environmental Protection Agency, 2006a, Total maximum daily loads-major pollutants causing impairment by State: accessed July 11, 2006, at URL http://www.epa. gov/owow/tmdl/303dcaus.html

U.S. Environmental Protection Agency, 2006b, Permit compliance system database: accessed July 12, 2006, at URL http://www.epa.gov/enviro/html/pcs/pcs_query.html

Viessman, W., Jr., Lewis, G.L., and Knapp, J.W., 1989, Introduction to hydrology (3d ed): New York, Harper and Row Publishers, $780 \mathrm{p}$.

Wagner, R.J., Mattraw, H.C., Ritx, G.F., and Smith, B.A., 2000, Guidelines and standard procedures for continuous water-quality monitors-Site selection, field operation, calibration, record computation, and reporting: U.S. Geological Survey Water-Resources Investigations Report 00-4252, $53 \mathrm{p}$.

Webb, W.E, Radtke, D.B, and Iwatsub, R.T., 1999, Surfacewater sampling-Collection methods at flowing-water and still-water sites, in Wilde, F.D., and Radtke, D.B., eds., 1999, Collection of water samples, in National field manual for the collection of water-quality data: U.S. Geological Survey Techniques of Water-Resources Investigations, book 9, chap. A4.1, 36 p. 
Appendix 1. Statistical summary of concentrations of ammonia nitrogen, nitrite plus nitrate, total phosphorus, orthophosphate, and suspended sediment in the Little River Basin, Kentucky, 2003-04.

$[\mathrm{N}$, nitrogen; $\mathrm{P}$, phosphorus; <, less than; ---, not applicable]

\begin{tabular}{|c|c|c|c|c|c|c|c|c|}
\hline \multirow[b]{2}{*}{ Constituent } & \multirow[b]{2}{*}{$\begin{array}{c}\text { Number } \\
\text { of } \\
\text { samples }\end{array}$} & \multirow[b]{2}{*}{$\begin{array}{c}\text { Number } \\
\text { of } \\
\text { detections }\end{array}$} & \multicolumn{6}{|c|}{$\begin{array}{l}\text { Concentrations, } \\
\text { in milligrams per liter }\end{array}$} \\
\hline & & & Minimum & $\begin{array}{c}25^{\text {th }} \\
\text { percentile }\end{array}$ & Mean & Median & $\begin{array}{c}75^{\text {th }} \\
\text { percentile }\end{array}$ & Maximum \\
\hline \multicolumn{9}{|c|}{$\begin{array}{l}\text { North Fork Little River near Hopkinsville, Kentucky } \\
\qquad \text { (03437400) }\end{array}$} \\
\hline $\begin{array}{l}\text { Ammonia (as N), } \\
\text { dissolved }\end{array}$ & 23 & 15 & $<0.04$ & $<0.04$ & 0.06 & $<0.04$ & 0.05 & 0.48 \\
\hline $\begin{array}{l}\text { Nitrite plus nitrate } \\
\text { (as } \mathrm{N}) \text {, dissolved }\end{array}$ & 23 & 23 & 1.3 & 2.2 & 3.1 & 2.9 & 3.8 & 5.3 \\
\hline $\begin{array}{l}\text { Phosphorus (as P), } \\
\text { total }\end{array}$ & 23 & 23 & .14 & .36 & .81 & .60 & 1.1 & 2.1 \\
\hline $\begin{array}{l}\text { Orthophosphate } \\
\text { (as P), dissolved }\end{array}$ & 23 & 23 & .05 & .26 & .70 & .48 & 1.0 & 2.0 \\
\hline $\begin{array}{r}\text { Suspended } \\
\text { sediment }\end{array}$ & 23 & --- & 1 & 4 & 35 & 7 & 56 & 201 \\
\hline \multicolumn{9}{|c|}{$\begin{array}{l}\text { South Fork Little River near Hopkinsville, Kentucky } \\
\qquad(03437600)\end{array}$} \\
\hline $\begin{array}{l}\text { Ammonia (as N), } \\
\text { dissolved }\end{array}$ & 23 & 3 & $<.04$ & $<.04$ & .07 & $<.04$ & $<.04$ & .66 \\
\hline $\begin{array}{l}\text { Nitrite plus nitrate } \\
\text { (as } \mathrm{N}) \text {, dissolved }\end{array}$ & 23 & 23 & 1.4 & 3.4 & 3.8 & 4.0 & 4.5 & 5.7 \\
\hline $\begin{array}{l}\text { Phosphorus (as P), } \\
\text { total }\end{array}$ & 23 & 23 & .02 & .04 & .09 & .06 & .10 & .39 \\
\hline $\begin{array}{l}\text { Orthophosphate } \\
\text { (as P), dissolved }\end{array}$ & 23 & 22 & $<.006$ & .02 & .05 & .03 & .05 & .25 \\
\hline $\begin{array}{r}\text { Suspended } \\
\text { sediment }\end{array}$ & 23 & --- & 1 & 3 & 28 & 5 & 39 & 182 \\
\hline \multicolumn{9}{|c|}{$\begin{array}{l}\text { Little River near Cadiz, Kentucky } \\
\qquad(03438000)\end{array}$} \\
\hline $\begin{array}{l}\text { Ammonia (as N), } \\
\text { dissolved }\end{array}$ & 23 & 4 & $<.04$ & $<.04$ & .03 & $<.04$ & $<.04$ & .11 \\
\hline $\begin{array}{l}\text { Nitrite plus nitrate } \\
\text { (as N), dissolved }\end{array}$ & 23 & 23 & 2.5 & 3.2 & 3.6 & 3.7 & 3.9 & 4.7 \\
\hline $\begin{array}{l}\text { Phosphorus (as P), } \\
\text { total }\end{array}$ & 23 & 23 & .06 & .11 & .17 & .16 & .20 & .49 \\
\hline $\begin{array}{l}\text { Orthophosphate } \\
\text { (as P), dissolved }\end{array}$ & 23 & 23 & .03 & .05 & .1 & .08 & .13 & .21 \\
\hline $\begin{array}{r}\text { Suspended } \\
\text { sediment }\end{array}$ & 23 & --- & 2 & 5 & 38 & 14 & 28 & 175 \\
\hline
\end{tabular}


Appendix 1. Statistical summary of concentrations of ammonia nitrogen, nitrite plus nitrate, total phosphorus, orthophosphate, and suspended sediment in the Little River Basin, Kentucky, 2003-04._Continued

$[\mathrm{N}$, nitrogen; $\mathrm{P}$, phosphorus; <, less than; ---, not applicable]

\begin{tabular}{|c|c|c|c|c|c|c|c|c|}
\hline \multirow[b]{2}{*}{ Constituent } & \multirow{2}{*}{$\begin{array}{c}\text { Number } \\
\text { of } \\
\text { samples }\end{array}$} & \multirow{2}{*}{$\begin{array}{c}\begin{array}{c}\text { Number } \\
\text { of } \\
\text { detections }\end{array} \\
\end{array}$} & \multicolumn{6}{|c|}{$\begin{array}{c}\text { Concentrations, } \\
\text { in milligrams per liter }\end{array}$} \\
\hline & & & Minimum & $\begin{array}{c}25^{\text {th }} \\
\text { percentile }\end{array}$ & Mean & Median & $\begin{array}{c}75^{\text {th }} \\
\text { percentile }\end{array}$ & Maximum \\
\hline \multicolumn{9}{|c|}{$\begin{array}{l}\text { Sinking Fork near Cadiz, Kentucky } \\
\qquad(03438040)\end{array}$} \\
\hline $\begin{array}{l}\text { Ammonia (as N), } \\
\text { dissolved }\end{array}$ & 23 & 3 & $<0.04$ & $<0.04$ & 0.02 & $<0.04$ & $<0.04$ & 0.10 \\
\hline $\begin{array}{l}\text { Nitrite plus nitrate } \\
\text { (as } \mathrm{N}) \text {, dissolved }\end{array}$ & 23 & 23 & 1.2 & 3.7 & 4.3 & 4.4 & 5.2 & 5.7 \\
\hline $\begin{array}{l}\text { Phosphorus (as P), } \\
\text { total }\end{array}$ & 23 & 23 & .03 & .06 & .14 & .07 & .11 & 1.0 \\
\hline $\begin{array}{l}\text { Orthophosphate } \\
\text { (as P), dissolved }\end{array}$ & 23 & 23 & .008 & .03 & .05 & .04 & .05 & .14 \\
\hline $\begin{array}{r}\text { Suspended } \\
\text { sediment }\end{array}$ & 23 & --- & 1 & 5 & 93 & 14 & 30 & 1,020 \\
\hline \multicolumn{9}{|c|}{$\begin{array}{l}\text { Little River at KY } 345 \text { near Cadiz, Kentucky } \\
\text { (03437680) }\end{array}$} \\
\hline $\begin{array}{l}\text { Ammonia (as N), } \\
\text { dissolved }\end{array}$ & 4 & 2 & $<.04$ & $<.04$ & .07 & $<.04$ & .07 & .22 \\
\hline $\begin{array}{l}\text { Nitrite plus nitrate } \\
(\text { as } \mathrm{N}) \text {, dissolved }\end{array}$ & 4 & 4 & 2.0 & 2.7 & 3.0 & 3.0 & 3.3 & 3.8 \\
\hline $\begin{array}{l}\text { Phosphorus (as P), } \\
\text { total }\end{array}$ & 4 & 4 & .17 & .29 & .31 & .34 & .37 & .39 \\
\hline $\begin{array}{l}\text { Orthophosphate } \\
\text { (as P), dissolved }\end{array}$ & 4 & 4 & .05 & .10 & .17 & .15 & .22 & .31 \\
\hline $\begin{array}{r}\text { Suspended } \\
\text { sediment }\end{array}$ & 4 & --- & 67 & 67 & 103 & 68 & 120 & 173 \\
\hline \multicolumn{9}{|c|}{$\begin{array}{l}\text { Muddy Fork near Hopkinsville, Kentucky } \\
\text { (03438024) }\end{array}$} \\
\hline $\begin{array}{l}\text { Ammonia (as N), } \\
\text { dissolved }\end{array}$ & 4 & 2 & $<.04$ & $<.04$ & $<.04$ & $<.04$ & $<.04$ & .05 \\
\hline $\begin{array}{l}\text { Nitrite plus nitrate } \\
\text { (as N), dissolved }\end{array}$ & 4 & 4 & 2.0 & 2.2 & 3.5 & 3.5 & 4.7 & 5.0 \\
\hline $\begin{array}{l}\text { Phosphorus (as P), } \\
\text { total }\end{array}$ & 4 & 4 & .04 & .05 & .15 & .08 & .18 & .40 \\
\hline $\begin{array}{l}\text { Orthophosphate } \\
\text { (as P), dissolved }\end{array}$ & 4 & 4 & .03 & .03 & .04 & .04 & .05 & .06 \\
\hline $\begin{array}{r}\text { Suspended } \\
\text { sediment }\end{array}$ & 3 & --- & 42 & 46 & 55 & 50 & 62 & 74 \\
\hline
\end{tabular}


Appendix 1. Statistical summary of concentrations of ammonia nitrogen, nitrite plus nitrate, total phosphorus, orthophosphate, and suspended sediment in the Little River Basin, Kentucky, 2003-04._Continued

[N, nitrogen; P, phosphorus; <, less than; ---, not applicable]

\begin{tabular}{|c|c|c|c|c|c|c|c|c|}
\hline \multirow[b]{2}{*}{ Constituent } & \multirow{2}{*}{$\begin{array}{c}\text { Number } \\
\text { of } \\
\text { samples }\end{array}$} & \multirow[b]{2}{*}{$\begin{array}{l}\text { Number of } \\
\text { detections }\end{array}$} & \multicolumn{6}{|c|}{$\begin{array}{l}\text { Concentrations, } \\
\text { in milligrams per liter }\end{array}$} \\
\hline & & & Minimum & $\begin{array}{c}25^{\text {th }} \\
\text { percentile }\end{array}$ & Mean & Median & $\begin{array}{c}75^{\text {th }} \\
\text { percentile }\end{array}$ & Maximum \\
\hline \multicolumn{9}{|c|}{$\begin{array}{l}\text { Sinking Fork near Hopkinsville, Kentucky } \\
\text { (03438028) }\end{array}$} \\
\hline $\begin{array}{l}\text { Ammonia (as N), } \\
\text { dissolved }\end{array}$ & 4 & 1 & $<0.04$ & $<0.04$ & $<0.04$ & $<0.04$ & $<0.04$ & $<0.04$ \\
\hline $\begin{array}{l}\text { Nitrite plus nitrate } \\
\text { (as N), dissolved }\end{array}$ & 4 & 4 & 1.3 & 1.8 & 2.3 & 2.4 & 2.9 & 3.1 \\
\hline $\begin{array}{l}\text { Phosphorus (as P), } \\
\text { total }\end{array}$ & 4 & 4 & .04 & .10 & .18 & .19 & .28 & .30 \\
\hline $\begin{array}{l}\text { Orthophosphate } \\
\text { (as P), dissolved }\end{array}$ & 4 & 4 & .01 & .02 & .05 & .04 & .06 & .09 \\
\hline $\begin{array}{r}\text { Suspended } \\
\text { sediment }\end{array}$ & 3 & --- & 40 & 100 & 157 & 161 & 216 & 271 \\
\hline \multicolumn{9}{|c|}{$\begin{array}{l}\text { Casey Creek near Cadiz, Kentucky } \\
\text { (03437990) }\end{array}$} \\
\hline $\begin{array}{l}\text { Ammonia (as N), } \\
\text { dissolved }\end{array}$ & 4 & 0 & $<.04$ & $<.04$ & $<.04$ & $<.04$ & $<.04$ & $<.04$ \\
\hline $\begin{array}{l}\text { Nitrite plus nitrate } \\
\text { (as N), dissolved }\end{array}$ & 4 & 4 & .36 & 1.7 & 1.8 & 2.3 & 2.3 & 2.4 \\
\hline $\begin{array}{l}\text { Phosphorus (as P), } \\
\text { total }\end{array}$ & 4 & 4 & .03 & .03 & .05 & .04 & .06 & .07 \\
\hline $\begin{array}{l}\text { Orthophosphate } \\
\text { (as P), dissolved }\end{array}$ & 4 & 3 & $<.006$ & .02 & .02 & .02 & .02 & .03 \\
\hline $\begin{array}{r}\text { Suspended } \\
\text { sediment }\end{array}$ & 4 & --- & $<1$ & 1 & 18 & 2 & 27 & 53 \\
\hline \multicolumn{9}{|c|}{$\begin{array}{l}\text { Little River at Crute Road near Cadiz, Kentucky } \\
\qquad \text { (03438080) }\end{array}$} \\
\hline $\begin{array}{l}\text { Ammonia (as N), } \\
\text { dissolved }\end{array}$ & 4 & 3 & $<.04$ & $<.04$ & $<.04$ & $<.04$ & .05 & .06 \\
\hline $\begin{array}{l}\text { Nitrite plus nitrate } \\
\text { (as N), dissolved }\end{array}$ & 4 & 4 & 2.8 & 3.2 & 3.4 & 3.5 & 3.7 & 3.7 \\
\hline $\begin{array}{l}\text { Phosphorus (as P), } \\
\text { total }\end{array}$ & 4 & 4 & .08 & .08 & .24 & .12 & .28 & .63 \\
\hline $\begin{array}{l}\text { Orthophosphate } \\
\text { (as P), dissolved }\end{array}$ & 4 & 4 & .05 & .05 & .08 & .08 & .11 & .11 \\
\hline $\begin{array}{r}\text { Suspended } \\
\text { sediment }\end{array}$ & 4 & --- & 5 & 9 & 142 & 22 & 154 & 518 \\
\hline
\end{tabular}


This page intentionally blank. 



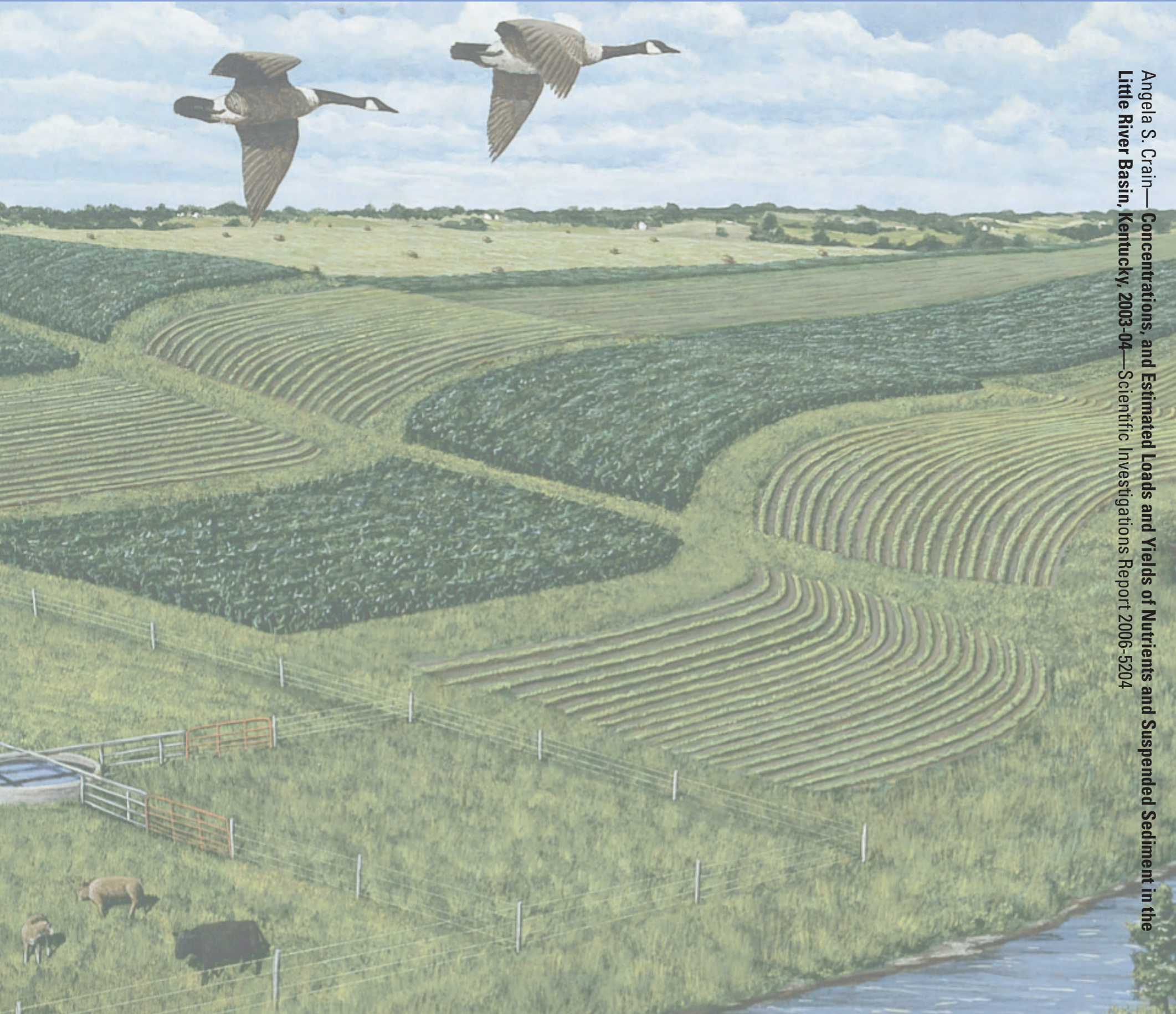

